\title{
The carbon budget of a winter wheat field: An eddy covariance analysis of seasonal and inter-annual variability
}

\author{
M. Schmidta ${ }^{\mathrm{a}, \mathrm{b}, 1}$, T.G. Reichenau ${ }^{\mathrm{a}, 1}$, P. Fiener $^{\mathrm{c}, \mathrm{a}}$, K. Schneider $^{\mathrm{a}, *}$ \\ a Institute of Geography, University of Cologne, 50923 Cologne, Germany \\ ${ }^{\mathrm{b}}$ Agrosphere Institute (IBG-3), Institute of Bio- and Geosciences, 52425 Jülich, Germany \\ ' Indo-German Centre of Sustainability, Indian Institute of Technology Madras, Chennai 600036 , India
}

\section{A R T I C L E I N F O}

\section{Article history:}

Received 18 May 2011

Received in revised form 17 May 2012

Accepted 21 May 2012

\section{Keywords:}

Winter wheat

Crop carbon balance

Net ecosystem exchange

Gross primary production

Ecosystem respiration

Eddy covariance

\begin{abstract}
A B S T R A C T
Arable land occupies large areas of global land surface and hence plays an important role in the terrestrial carbon cycle. Therefore agro-ecosystems show a high potential of mitigating greenhouse gas emissions while optimizing agricultural management. Hence, there is a growing interest in analyzing and understanding carbon fluxes from arable land as affected by regional environmental as well as management conditions. The major goal of this study is to use a two year data set of eddy covariance measurements (October 2007 to October 2009) on a winter wheat field located in Western Germany to assess the seasonal and inter-annual variability of carbon fluxes as affected by meteorological variables and land management. During the study period, which was comprised of two full growing seasons, eddy covariance measurements together with measurements of various soil, plant, and meteorological data were performed. Flux partitioning and gap filling methods including uncertainty estimates were applied to derive complete time series of net ecosystem exchange (NEE), gross primary production (GPP), and ecosystem respiration $\left(R_{\text {eco }}\right)$. Despite different management dates and slightly different meteorological conditions, annual NEE resulted in $270 \mathrm{~g} \mathrm{C} \mathrm{m}^{-2}$ in both years. Although the period from sowing to harvesting was more than 20 days shorter in the first year, due to the later start of senescence, GPP was higher by $220 \mathrm{~g} \mathrm{C} \mathrm{m}^{-2}$. In the annual carbon budget this was compensated by a stronger heterotrophic respiration after the harvest of sugar beet grown on the field before the study period. Taking into account the carbon losses due to removal of biomass during harvest, the winter wheat field acts as a carbon source with respective net biome productivities (NBP) of 246 and $201 \mathrm{~g} \mathrm{C} \mathrm{m}^{-2} \mathrm{a}^{-1}$. To complete the carbon balance, releases due to energy consumption associated with crop production are taken into account. However, the relatively large carbon loss was probably, to a large extent, compensated by carbon input from plant residues left on the field after preceding sugar beet harvest. This underlines the importance of multi-annual measurements taking full crop rotations into account.
\end{abstract}

(c) 2012 Elsevier B.V. All rights reserved.

\section{Introduction}

At present, $10.8 \%$ of the global land surface (12.6\% of Europe and $34.1 \%$ of Germany) is occupied by crops (FAO, 2007). Due to this large area and the strong impact of land use management upon plant growth and carbon fluxes in agroecosystems, these areas have a large potential to mitigate greenhouse gas emissions (e.g., Smith et al., 2007). The most promising option to encourage carbon sequestration in agricultural soils is a change in agricultural practice, e.g., a ban of residue burning or a change in tillage practice (e.g., Lal and Kimble, 1997; Freibauer et al., 2004; Smith, 2004; Ciais et al., 2010). In general, the increasing interest in carbon

\footnotetext{
* Corresponding author. Tel.: +49 470 4331; fax: +49 4705124

E-mail address: karl.schneider@uni-koeln.de (K. Schneider).

1 These authors contributed equally to this work.
}

sequestration or reduced mineralization in cropland soils has inspired a large number of studies focusing on carbon fluxes. Recent publications concentrate on multi-year studies or on large scale carbon balances (e.g., Janssens et al., 2005; Smith et al., 2007; Ciais et al., 2010; Schulze et al., 2010; Kutsch et al., 2010; Ceschia et al., 2010).

The net carbon exchange between arable fields and the atmosphere were studied for winter wheat (Falge et al., 2001b; Anthoni et al., 2004; Jun et al., 2006; Moureaux et al., 2008; Aubinet et al., 2009; Béziat et al., 2009; Lei and Yang, 2010), sugar beet (Moureaux et al., 2006; Aubinet et al., 2009), and maize (e.g., Suyker et al., 2005; Verma et al., 2005; Béziat et al., 2009; Bavin et al., 2009). Many of the earlier eddy covariance studies on arable land focused on carbon exchange during single years or growing seasons (e.g., Anthoni et al., 2004; Moureaux et al., 2006). These short term measurements are somewhat difficult to interpret with respect to developing potential mitigation techniques or evaluating the 


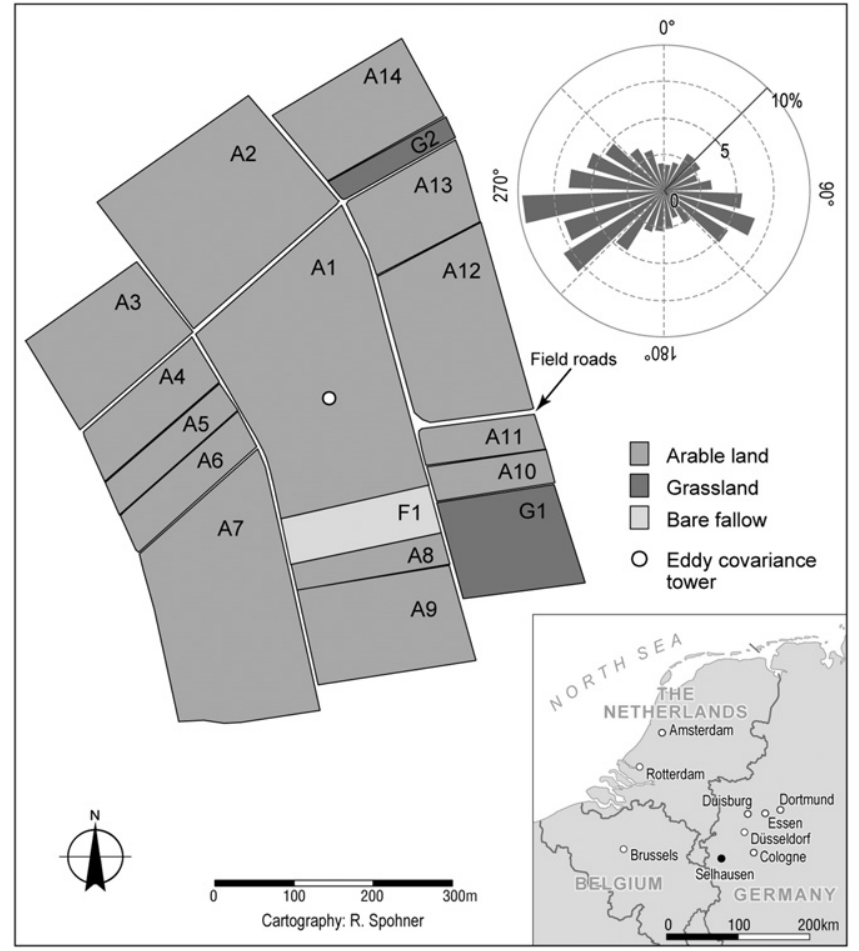

Fig. 1. Location of the Selhausen test site (winter wheat field in the center) and map of the surrounding agricultural fields. The frequency distribution of the wind direction was calculated from data measured between 19 October 2007 and 18 October 2009.

effects of new crops as the carbon exchange from a single cropping year might be biased by the meteorologic conditions, the carbon balance of preceding crops and/or the soil management within the year under study. The importance of estimating average carbon fluxes for a specific crop or crop rotation at a specific location becomes obvious when comparing long-term changes in SOC stocks (e.g., Goidts et al., 2009) with short-term results from carbon flux measurements. Consequently, there is a need to expand the measuring periods for eddy covariance studies, focusing on multiyear cropping and/or full crop rotations (Jun et al., 2006; Aubinet et al., 2009; Béziat et al., 2009; Lei and Yang, 2010). However, studies focusing on inter-annual differences in seasonality of carbon exchange of single crops at a single location (e.g., Dufranne et al., 2011), which allow analyzing meteorological and/or management effects, are still rare. The overall aim of this study was to analyze and understand the seasonal patterns and inter-annual differences of carbon exchange in a winter wheat field during a two year observation period. Specific aims were: (1) to derive a consistent 2 year data set of daily carbon fluxes based on eddy covariance measurements, (2) to compare the differences in seasonality of carbon fluxes and differences in carbon balance, and (3) to identify the impact of meteorology and agricultural management on measured carbon fluxes.

\section{Materials and methods}

\subsection{Test site}

The Selhausen test site $\left(50^{\circ} 52^{\prime} 14^{\prime \prime} \mathrm{N}, 6^{\circ} 26^{\prime} 58^{\prime \prime} \mathrm{E}, 103 \mathrm{~m}\right.$ above sea level) is located in the western part of Germany close to the Belgium border. The area belongs to the southern part of the Lower Rhine Embayment. The dominant land use is cropland. The test site consists of a single 6.58 ha field (see Fig. 1) on a slight slope $\left(<4^{\circ}\right)$.
Table 1

Major management activities at the test site during the observation period.

\begin{tabular}{|c|c|}
\hline Date & Management \\
\hline 18 October 2007 & $\begin{array}{l}\text { Harvesting of sugar beets } \\
\text { ( } 750 \mathrm{~g} \mathrm{C} \mathrm{m}^{-2} \text { was left in the residues on the field) }\end{array}$ \\
\hline \multirow[t]{3}{*}{19 November 2007} & Plowing \\
\hline & Rotary harrow, roller \\
\hline & Sowing of winter wheat \\
\hline 28 February 2008 & Fertilization: $22 \mathrm{~kg} \mathrm{~N} \mathrm{ha}^{-1}$ \\
\hline \multirow[t]{2}{*}{9 April 2008} & Weed control: $0.031 \mathrm{ha}^{-1}$ \\
\hline & Straw shortener: $0.0151 \mathrm{ha}^{-1}$ \\
\hline 18 April 2008 & Fertilization: $10 \mathrm{~kg} \mathrm{~N} \mathrm{ha}^{-1}$ \\
\hline 7 May 2008 & Fungicide treatment: $0.031 \mathrm{ha}^{-1}$ \\
\hline 20 May 2008 & Fertilization: $22 \mathrm{~kg} \mathrm{~N} \mathrm{ha}^{-1}$ \\
\hline \multirow[t]{2}{*}{6 June 2008} & Fungicide treatment: $0.0181 \mathrm{ha}^{-1}$ \\
\hline & Insecticide treatment: $0.075 \mathrm{lha}^{-1}$ \\
\hline \multirow[t]{4}{*}{6 August 2008} & Harvesting of winter wheat \\
\hline & Crop yield: $0.98 \mathrm{~kg} \mathrm{~m}^{-2}$ (0.83 $\mathrm{kg} \mathrm{m}^{-2}$ dry grains) \\
\hline & (132 $\mathrm{g} \mathrm{C} \mathrm{m}^{-2}$ was left in the residues on the field) \\
\hline & ( $182 \mathrm{~g} \mathrm{C} \mathrm{m}^{-2}$ was removed with the straw) \\
\hline 5 September 2008 & Plowing \\
\hline \multirow[t]{2}{*}{18 October 2008} & Rotary harrow, roller \\
\hline & Sowing of winter wheat \\
\hline 18 March 2009 & Fertilization: $17 \mathrm{~kg} \mathrm{~N} \mathrm{ha}^{-1}$ \\
\hline 2 April 2009 & Weed control: $0.037 \mathrm{lha}^{-1}$ \\
\hline 14 April 2009 & Fertilization: $8 \mathrm{~kg} \mathrm{~N} \mathrm{ha}{ }^{-1}$ \\
\hline 19 May 2009 & Fertilization: $19 \mathrm{~kg} \mathrm{~N} \mathrm{ha}^{-1}$ \\
\hline 2 May 2009 & Fungicide treatment: $0.031 \mathrm{ha}^{-1}$ \\
\hline 31 May 2009 & Fungicide treatment: $0.0361 \mathrm{ha}^{-1}$ \\
\hline \multirow[t]{4}{*}{28 July 2009} & Harvesting of winter wheat \\
\hline & crop yield: $0.86 \mathrm{~kg} \mathrm{~m}^{-2}$ (0.73 $\mathrm{kg} \mathrm{m}^{-2}$ dry grains $)$ \\
\hline & (132 $\mathrm{g} \mathrm{C} \mathrm{m}^{-2}$ was left in the residues on the field) \\
\hline & (196 $\mathrm{g} \mathrm{C} \mathrm{m}^{-2}$ was removed with the straw) \\
\hline 5 August 2009 & Plowing \\
\hline
\end{tabular}

The eddy covariance tower was placed in the center of the field. The fetch in the main wind directions ranges from $135 \mathrm{~m}(\mathrm{~W})$ to $90 \mathrm{~m}$ (ESE). The mean wind speed during the investigation period was $2.3 \mathrm{~m} \mathrm{~s}^{-1}$.

The climate can be characterized as temperate maritime with a mean annual temperature of $9.9{ }^{\circ} \mathrm{C}$ and annual precipitation of $698 \mathrm{~mm}$ (1961-2008, German weather service station Juelich (Kernf.-Anlage), Stat-ID 2474, about $5 \mathrm{~km}$ north-west of the test site).

The underlying Quaternary sediments are mostly fluvial deposits from the Rhine/Meuse and the Rur river systems and are covered by loess (up to a depth of $1 \mathrm{~m}$ ). The major soil type is classified as a Luvisol (IUSS Working Group WRB, 2006). It is composed of approx. $16 \%$ clay, $68 \%$ silt and $15 \%$ sand, indicating a silt loam.

The test field (A1, Fig. 1) is surrounded by agricultural fields separated by small field paths and a small road (no public traffic) on the east side. Except for a narrow field on the southern border of the test site, which is kept free of vegetation, the surrounding fields were cultivated with winter wheat, sugar beet, rye, barley, and maize. All fields were conventionally managed.

The test field has a winter wheat/winter wheat/sugar beet rotation, whereof the winter wheat years (October 2007-October 2009) were monitored. Before planting winter wheat in 2007, the entire sugar beet crop residues (leaves, stems, beet crowns) were left on the field and the soil was tilled to a depth of approx. $0.30 \mathrm{~m}$. Winter wheat (Triticum aestivum L.; variety Raspail) was sown in row distances of approx. $0.12 \mathrm{~m}$ and was harvested on 6 August 2008 . Wheat stubbles were left on the field, while the straw was removed. On 5 September 2008, the soil was tilled and winter wheat was sown on 18 October 2008, about one month earlier than in 2007. The crop was harvested on 28 July 2009, about one week earlier than the year before (Table 1 ). 


\subsection{Measurements}

\subsubsection{Eddy covariance measurements}

Net ecosystem exchange (NEE), latent heat (LE), and sensible heat $(\mathrm{H})$ were measured continuously between 19 October 2007 and 18 October 2009 using the eddy covariance method. Wind components and sonic temperature were measured with a three dimensional sonic anemometer (CSAT3, Campbell Scientific, Inc., Logan, UT, USA). Measurements of water vapor $\left(\mathrm{H}_{2} \mathrm{O}\right)$ and carbon dioxide $\left(\mathrm{CO}_{2}\right)$ density were carried out using an open-path infrared gas analyzer (IRGA, model LI7500, LI-COR Inc., Lincoln, NE, USA). These instruments were mounted on a small tower (height: $3 \mathrm{~m}$ ).

Measurements were taken with a sampling rate of $20 \mathrm{~Hz}$ and collected as raw time series, using a high performance data logger (CR5000, Campbell Scientific, Inc., Logan, UT, USA). Sensors for flux measurement were mounted at a varying height of 1.7-2.0 $\mathrm{m}$ above ground level. The varying measuring height was a compromise between: (1) the requirement to measure above the zero-plane displacement height, which as a rule of thumb, extends from the ground to two-thirds of the canopy height (Foken, 2003) and (2) the aim to keep the footprint of the measurements as small as possible to obtain fluxes that are less influenced by adjacent agricultural fields.

\subsubsection{Ancillary environmental measurements}

During the whole observation period, the following ancillary measurements were carried out at 30 min intervals: Measurements of global radiation $(R)$ and net radiation $(Q)$ were performed with a silicon pyranometer (SP-LITE, Kipp \& Zonen, Delft, Netherlands) and a net radiometer (NR-LITE, Kipp \& Zonen, Delft, Netherlands), mounted at a height of $2.5 \mathrm{~m}$. Air temperature and relative humidity were measured with a combined temperature and humidity sensor (CS215, Campbell Scientific, Inc., Logan, UT, USA) installed at a height of $2.2 \mathrm{~m}$. Precipitation was measured at a height of $1.0 \mathrm{~m}$ using a tipping bucket rain gauge (RM Young 52203 Tipping Bucket Rain Gauge, R.M. Young Company, Traverse City, USA) positioned a few meters beside the tower. Soil temperature was measured at a depth of $0.05 \mathrm{~m}$ with a temperature thermocouple probe (TCAV, Campbell Scientific, Inc., Logan, UT, USA). Volumetric soil water content (SWC) was measured using two water content reflectometers (CS616, Campbell Scientific, Inc., Logan, UT, USA) placed at 0.1 and $0.3 \mathrm{~m}$ below the surface. Soil heat flux $(G)$ was measured using a soil heat flux plate (HFP01, Hukseflux Thermal Sensors, Delft, Netherlands) deployed at a depth of $0.08 \mathrm{~m}$. The storage term of the soil heat flux was calculated according to Campbell Scientific (2003) and added to the measured soil heat flux.

\subsubsection{Biometric measurements}

From 4 March 2007 to 27 July 2009 biometric measurements were carried out bi-weekly during the growing seasons to monitor crop development and growth stage. At a minimum of three sampling locations canopy height, phenological stage (BBCH-scale; Meier, 2001) and plant density were determined. Plants from sections of $50 \mathrm{~cm}$ length were harvested over three rows at each sampling location and subsequently analyzed in the lab to measure fresh and dry biomass and leaf area index (LAI). Belowground biomass was not collected. Additional data on sugar beet biomass from the period before the sowing of winter wheat were achieved in a similar manner.

In the laboratory, harvested biomass of each sampling location was divided into aliquots of at least $150 \mathrm{~g}$ and subsequently separated into living (green) and senescent (brown/yellow) leaves, stems (including leaf sheath) and ears (including grain, glume and rest of the ear). LAI of living, green leaves (GLAI) and senescent, brown leaves (BLAI) was determined with a LI-3000A Area Meter (LI-COR Biosciences, Lincoln, NE, USA).

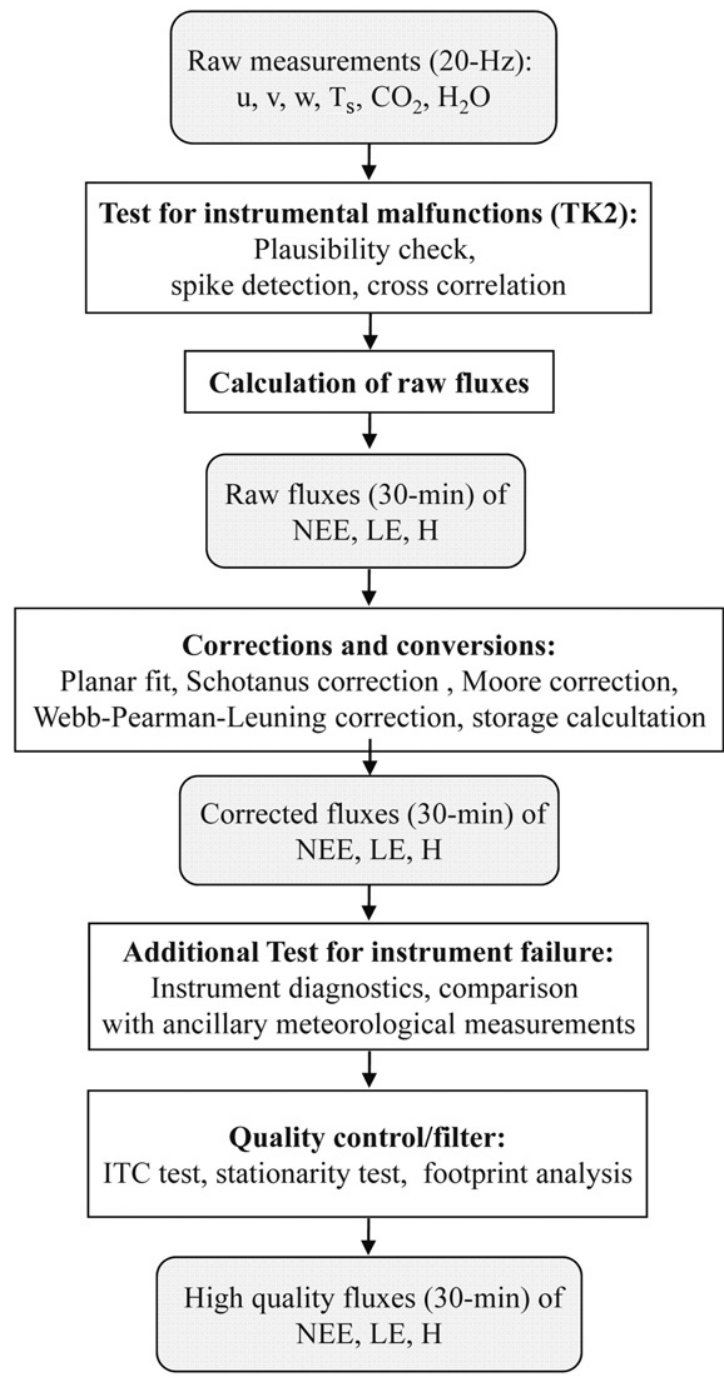

Fig. 2. General scheme of the processing of eddy covariance fluxes of net ecosystem exchange of $\mathrm{CO}_{2}$ (NEE), latent heat flux (LE), sensible heat flux $(\mathrm{H})$, including the applied tests, quality controls, corrections and processing steps. Raw measurements of longitudinal (u), lateral (v), and vertical (w) wind velocities and sonic temperature $\left(\mathrm{T}_{\mathrm{s}}\right)$ were made with a sonic anemometer. Raw measurements of carbon dioxide $\left(\mathrm{CO}_{2}\right)$ and water vapor $\left(\mathrm{H}_{2} \mathrm{O}\right)$ density were performed with an infrared gas analyzer.

For the determination of dry matter (DM), aliquots of living and senescent leaves, stems and ears were oven-dried at $105^{\circ} \mathrm{C}$ for at least $24 \mathrm{~h}$. Furthermore, additional aliquots of the dried plant material were homogenized in a mortar and subsequently ground in a planetary mill to determine the total content of carbon and nitrogen with an elemental analyzer (CNS Elemental Analyzer Vario EL, Elementar Analysensysteme GmbH, Hanau, Germany).

\subsection{Processing of EC data}

A series of post-processing steps, outlined in the following paragraphs, must be performed on the EC measurements to provide data suitable for flux analysis (Fig. 2).

\subsubsection{Calculation of raw fluxes}

The high resolution time series $(20 \mathrm{~Hz})$ of wind components $(\mathrm{u}, \mathrm{v}, \mathrm{w})$, sonic temperature $\left(\mathrm{T}_{\mathrm{s}}\right), \mathrm{CO}_{2}$, and water vapor density were used to calculate fluxes of NEE, LE and $\mathrm{H}$ using the software TK2 (University of Bayreuth, Department of Micrometeorology, Germany). 
At first, raw measurements were checked with a plausibility test to exclude physically invalid values. Therefore thresholds, representing realistic ranges for each parameter were defined. In addition, raw measurements were checked using a spike detection algorithm of Vickers and Mahrt (1997), which rejects any values that exceed 3.5 times the standard deviation in a moving window of 10 values, unless four or more values in a row meet this criterion.

In order to remove the time lag between sonic anemometer and IRGA measurements, a cross correlation analysis for each $30 \mathrm{~min}$ interval was applied. The lag with the highest correlation between the time series of both instruments was used for synchronization.

After testing and correcting the $20 \mathrm{~Hz}$ measurements, raw fluxes of NEE, LE, and $\mathrm{H}$ were calculated as the covariance between the high frequency time series of the vertical wind speed $(w)$ and the respective measurement of temperature, carbon, or water vapor content by Reynolds averaging (Reynolds, 1894) of 30-min blocks of data (Aubinet et al., 2000; Baldocchi, 2003; Grelle and Lindroth, 1996).

\subsubsection{Corrections and conversions}

Since the plants grow in height $(0-0.8 \mathrm{~m})$ during the vegetation period, the planar fit following the method of Wilczak et al. (2001) was applied to consecutive two week periods. During periods with strong plant growth, this period was reduced to ten days.

The sensible heat flux was corrected for humidity effects according to Schotanus et al. (1983) as modified by Liu et al. (2001).

To account for spectral loss due to high-pass and low-pass filtering during the measurements, frequency response corrections according to Moore (1986) were applied to the raw fluxes using the spectral models by Kaimal et al. (1972) and Hojstrup (1981). To correct the turbulent fluxes of $\mathrm{CO}_{2}$ and water vapor for fluctuations of air temperature and water vapor density, the Webb-Pearman-Leuning (WPL, Webb et al., 1980) correction was used.

To retrieve NEE, a storage term was added to the turbulent flux of $\mathrm{CO}_{2}$. The storage of atmospheric $\mathrm{CO}_{2}$ in the volume between the ground and the level of the instruments was calculated based on the assumption that the 30 -min changes in carbon dioxide concentration at the instrument level are representative for the whole air layer below the EC system (Hollinger et al., 1994; Greco and Baldocchi, 1996). Nevertheless, it should be mentioned that this method typically underestimates this comparatively small $\mathrm{CO}_{2}$ storage term by $20-25 \%$ (Saito et al., 2005).

\subsubsection{Additional test for instrument failure}

Inaccurate gas density measurements caused by pollution of the focus lens of the open path IRGA due to rain, dew, or dust on the surface cause large absolute variations in measured carbon and water vapor content (Leuning and Judd, 1996; Serrano-Ortiz et al., 2008; Heusinkveld et al., 2008). To exclude inaccurate IRGA measurements caused by pollution of the lens (Leuning and Judd, 1996; Serrano-Ortiz et al., 2008; Heusinkveld et al., 2008), the internally derived value of the automatic gain control (AGC) was used as a quality control.

Because the measurements of the combined humidity and temperature sensor are (contrary to the IRGA) not affected by dust and water on the sensor surface and thus show very robust measurements, they can be used to further test the IRGA measurements. Absolute humidity derived from IRGA was compared to those measured with the combined humidity and temperature sensor. Thirty minute flux data were rejected if the difference exceeded an empirically derived threshold of $0.9 \mathrm{~g} \mathrm{H}_{2} \mathrm{O} \mathrm{m}^{-2}$.

\subsubsection{Data quality and data filtering}

The corrected fluxes of NEE, LE and $\mathrm{H}$ were subjected to a series of quality checks, partly used to filter flux data with low quality: To check whether the theoretical requirements for the EC method were met, the integral turbulence characteristics test and the steady state test (Foken and Wichura, 1996) were applied. As part of the software package TK2, the results of these tests were consolidated in an overall flag system according to the scheme of the Spoleto agreement for the CarboEurope-IP (Mauder and Foken, 2004). Based on this scheme, all 30-min fluxes were classified as high, moderate, or low quality data (see Foken et al., 2004). Only fluxes classified as high quality data were used for the further analysis.

Despite the low height of the EC measurement of only 1.7-2.0 m, some contamination of the measured fluxes through fluxes from neighboring fields can be expected due to the relatively small field size, which is typical for this intensively used cropping area in Germany. To exclude these flux measurements, the footprint tool of Neftel et al. (2008) was used. This tool is based on the footprint model of Kormann and Meixner (2001) and provides the cumulative source contribution (CSC) of the test site and surrounding fields (expressed in percent) to each 30 -min flux interval. Applying a footprint filter using the threshold of $80 \%$ CSC from the test site (a value often found in the literature), resulted in a data coverage of $31.5 \%$ of the daytime and $4.7 \%$ of the nighttime flux measurements.

In order to prevent an extensive rejection of data and to retain a reasonable amount of measurements for carbon budget estimations and analysis of the nighttime processes, we followed the approach of Ammann et al. (2007) subdividing the dataset into nighttime and daytime measurements with individual CSC thresholds. A threshold of 70\% CSC was set for daytime observations while the threshold for nighttime observations was relaxed to $50 \%$. Fluxes that did not match these thresholds were rejected from further analysis.

\subsubsection{Test on energy balance closure}

A standard method to check EC measurements for plausibility is the comparison between measured latent and sensible heat fluxes and measured net radiation and ground heat flux (e.g., Wilson et al., 2002) using the energy balance equation:

$\mathrm{Q}-\mathrm{G}=\mathrm{LE}+\mathrm{H}+\operatorname{Res}$

where $Q$ is net radiation, $G$ is ground heat flux and LE and $H$ are eddy covariance fluxes for latent and sensible heat, respectively. The residual term Res accounts for the energy balance closure gap, which includes all fluxes not or inaccurately measured by the EC method (i.e., advection terms, canopy heat storage, and others). All units are in $\mathrm{W} \mathrm{m}^{-2}$.

To determine the energy balance closure, we applied two methods: (1) a linear regression between the available energy $(Q-G)$ and the energy fluxes $(\mathrm{LE}+\mathrm{H})$ and $(2)$ the calculation of the mean residual (Res in Eq. (1)).

\subsection{Determination of carbon budgets}

Using the EC method to analyze seasonal and inter-annual dynamics including long-term budgets of carbon requires a gap filling of meteorological and carbon flux data as well as a flux partitioning of the measured NEE into gross primary production (GPP) and ecosystem respiration ( $\left.\mathrm{R}_{\mathrm{eco}}\right)$.

Gaps in the low frequency meteorological data were filled first, because complete time series, especially of air temperature and radiation, are needed for the following carbon flux gap filling. Small gaps of up to $3 \mathrm{~h}$ were interpolated and larger gaps were filled with appropriate measurements of the nearby station from the German weather service. If no measurements were available, the mean diurnal variation approach (Falge et al., 2001a) was used to fill the gaps. 
Due to absence of photosynthesis, measured nighttime NEE

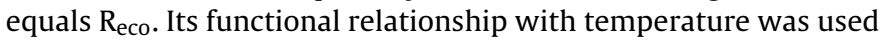
to fill gaps in the nighttime time series where nighttime was defined as periods with global radiation of less than $1 \mathrm{~W} \mathrm{~m}^{-2}$. Nighttime NEE was not used if soil temperature was below $1^{\circ} \mathrm{C}$. The nighttime relationship was used to calculate $\mathrm{R}_{\mathrm{eco}}$ during daytime, assuming that the temperature dependency of respiration is the same during daytime and nighttime. The Lloyd-and-Taylor model (Lloyd and Taylor, 1994) was used to derive Reco from temperature measurements:

$R_{\text {eco }}=R_{\text {ref }} \cdot e^{E_{0}\left(1 /\left(T_{\text {ref }}-T_{0}\right)-1 /\left(T_{\text {air }}-T_{0}\right)\right)}$

where $R_{\text {ref }}\left(\mu \mathrm{mol} \mathrm{m}{ }^{-2} \mathrm{~s}^{-1}\right)$ is respiration at reference temperature $\mathrm{T}_{\mathrm{ref}}(\mathrm{K}), \mathrm{E}_{0}(\mathrm{~K})$ is activation energy that is written as an energy interval using the temperature scale, $T_{0}$ is base temperature and $\mathrm{T}_{\text {air }}(\mathrm{K})$ is air temperature. To avoid over-parameterization, $\mathrm{T}_{0}$ was kept constant at $227.13 \mathrm{~K}$ (Richardson and Hollinger, 2005) and $\mathrm{T}_{\text {ref }}$ was set to $283.15 \mathrm{~K}$ (Lloyd and Taylor, 1994). Air temperature was chosen as the principal driver. Based on tests, we found that using air temperature results in better reproduction of measured data than the use of soil temperature. This is probably due to the importance of plant temperature and the spatially less variable character of air temperature as compared to soil temperature (measured at a single location).

Based on the assumption that $\mathrm{R}_{\mathrm{ref}}$ and $\mathrm{E}_{0}$ vary over time, a moving window with a time-shift of one day was used to fit Eq. (2) to $\mathrm{R}_{\text {eco }}$ versus air temperature $\left(\mathrm{T}_{\text {air }}\right)$ using the ordinary least squares method. The fitting of $R_{r e f}$ and $E_{0}$ was accomplished subsequently. $\mathrm{R}_{\mathrm{ref}}$ was fitted first with $\mathrm{E}_{0}$ kept constant at $270 \mathrm{~K}$. In a next step $\mathrm{E}_{0}$ was fitted using the previously derived values of $R_{\text {ref }}$. Fitted values were assigned to the date in the middle of the data window. Starting with a length of four days, the window was extended until a minimum of 15 measurements of Reco was available and the temperature range was at least $3^{\circ} \mathrm{C}$. Fits resulting in implausible values of $R_{r e f}$ and $E_{0}$ were rejected and the data window was extended. Half-hourly time series of $\mathrm{R}_{\text {ref }}$ and $\mathrm{E}_{0}$ were derived by linear interpolation and subsequently used with Eq. (2) to create a complete time series of $\mathrm{R}_{\mathrm{eco}}$. According to Reichstein et al. (2005), the nighttime measurements that were used for the calculation of $R_{\text {eco }}$ were substituted by the modeled values of $R_{\text {eco }}$.

After the complete time series of $R_{\text {eco }}$ had been calculated, the following basic equation was used to derive GPP:

$\mathrm{GPP}=\mathrm{NEE}-\mathrm{R}_{\mathrm{eco}}$

The sign of the flux follows the micrometeorological convention that fluxes from the atmosphere to the surface are negative and vice versa. Due to the incomplete time series of NEE measurements, there were still gaps in derived GPP. For gap filling of the GPP time series, a nonrectangular hyperbolic relationship based on Rabinowitch (1951) was used:

$\mathrm{GPP}=\frac{1}{2 \theta}\left(\alpha \mathrm{Q}+\mathrm{A}_{\max }-\sqrt{\left(\alpha \mathrm{Q}+\mathrm{A}_{\max }\right)^{2}-4 \alpha \mathrm{A}_{\max } \theta \mathrm{Q}}\right)$

where $\theta$ is the curvature of light response curve, $\alpha\left(\mu \mathrm{mol} \mu \mathrm{mol}^{-1}\right)$ is the apparent quantum efficiency (initial slope of the light response curve), $Q\left(\mu \mathrm{mol} \mathrm{m}{ }^{-2} \mathrm{~s}^{-1}\right)$ is the photosynthetic photon flux density (PPFD) and $A_{\max }\left(\mu \mathrm{mol} \mathrm{m}^{-2} \mathrm{~s}^{-1}\right.$ ) is maximum gross photosynthesis. Assuming that $45 \%$ of measured global radiation is the photosynthetic active radiation (PAR, Meek et al., 1984), and one Watt of PAR is equal to $4.6 \mu \mathrm{mol} \mathrm{m}^{-2} \mathrm{~s}^{-1}$ (Campbell and Norman, 1998), measurements of global radiation were converted into photosynthetic photon flux density.

Again a moving data window was used to account for temporal variations of $\theta, \alpha$ and $A_{\max }$, by fitting them simultaneously to GPP versus $Q$. Similar to the procedure during the gap filling of $R_{\text {eco, }}$, the window was extended if it contained less than 21 datasets. Fits resulting in implausible values were rejected and the window was extended. If a quality-check of the results of the fitting procedure against measured GPP failed $\left(r^{2}<0.68\right)$, the moving window was extended and GPP was recalculated. If there was no successful fit until the length of the window reached 35 days (which occurs outside the growing season) GPP was set to zero. Half-hourly time series of $\theta, \alpha$, and $A_{\max }$ were created by linear interpolation and were subsequently used to derive a complete time series of GPP. Finally, Eq. (3) was used to fill the gaps in the time series of NEE, by using the derived time series of $R_{\text {eco }}$ and GPP.

For further analysis, the gap filled half-hourly values of NEE, GPP and $R_{\text {eco }}$, expressed in $\mu \mathrm{mol} \mathrm{m}{ }^{-2} \mathrm{~s}^{-1}$ were integrated into daily, seasonal or annual sums in $\mathrm{g} \mathrm{C}^{-2}$.

To account for management effects net biome production $\left(\mathrm{g} \mathrm{C} \mathrm{m}^{-2}\right)$ was defined as:

$\mathrm{NBP}=\mathrm{NEE}+\mathrm{IMP}+\mathrm{EXP}$

where IMP (counted negative) is the import of carbon, caused by the application of organic fertilizer (which does not apply to the test site) or the sowing of winter wheat seeds, and EXP is the export of harvest materials. Both terms were determined by combining information provided by the farm manager of the test site and the measurement of carbon content from the last plant sample before harvest. The carbon input through winter wheat grains was determined using the farmer's information of the sowing amount while assuming a grain $C$ content of $42.9 \%$. For determining EXP, yield data (dry yield of grain and straw) and carbon contents of grain and straw was used.

\subsection{Uncertainty analysis}

Instrument failure as well as quality and footprint checks cause a considerable fraction of missing values in the time series of carbon fluxes. Despite using sophisticated methods to fill the gaps, the filled values introduce an uncertainty into the carbon balance calculations that adds to the uncertainty due to errors of the measurement instruments. To assess the uncertainty arising from the gap filling procedure and from random measurement errors, an uncertainty analysis based on the method described by Richardson and Hollinger (2007) was performed separately for both years.

To asses the uncertainty due to the filling of long gaps, the parameters fitted during the gap filling procedure were jointly used with the temperature and radiation data to create a synthetic time series. Thirty percent of the values of this time series were removed by randomly introducing half-hourly gaps. In addition to these short gaps, long gaps with a length of one to 27 days using only odd number of days were added. The starting date of these long gaps was systematically moved throughout the year beginning with day one using an increment of two days. This results in separate time series for each gap length and starting date, respectively. Gap filling was carried out for each of these time series and annual sums of NEE, GPP, and $R_{\text {eco }}$ were calculated. Differences of these annual sums from the annual sums of the time series without a long gap were grouped with respect to the month of the starting date of the long gap. In each of the monthly groups the standard deviation of the differences was calculated for each long gap length. A linear regression of the standard deviations against the gap length was conducted for each monthly group. The resulting monthly linear relationships between gap length and standard deviation were then applied to the gaps in the measured time series. For each gap the standard deviation was calculated by inserting the gap length into the linear equation for the month of the gap's starting date. The overall uncertainty was calculated by adding these standard deviations in quadrature.

To asses the uncertainty due to random measurement errors a Monte Carlo analysis was performed. Following Richardson 
and Hollinger (2007) synthetic scatter and random gaps were applied to the synthetic time series (as described above) followed by the gap filling procedure. After 100 repetitions the standard deviation of the resulting annual sums was used as a measure for the uncertainty due to random measurement error.

\subsection{Definition of evaluation periods}

To compare carbon budgets of NEE, GPP and $R_{\text {eco }}$ of the two different years, we defined several evaluation periods, representing seasonal patterns, caused by effects of wheat phenology:

1. Annual: The period between 19 October and 18 October;

2. Main growing season (MGS): This period excludes the winter period with low crop related dynamics and in turn represents the period where photosynthesis within the field is significant. The threshold for beginning and end of MGS is set as the 50th percentile of GPP between sowing and harvesting $(-1.3$ and $-0.86 \mathrm{~g} \mathrm{C} \mathrm{m}^{-2} \mathrm{~d}^{-1}$ in the first year 1 ( yr1) and the second year (yr2), respectively). Beginning of MGS is set when GPP falls below that threshold for at least four consecutive days. MGS ends if GPP exceeds this threshold for at least four consecutive days;
3. Off-main growing season (oMGS): The periods where plant activity shows no significant effect on carbon fluxes. These are the periods between the beginning of the observation year and the beginning of the MGS and between the end of the MGS and the end of the respective year.

\section{Results and discussion}

\subsection{Meteorological conditions and crop development}

Annual meteorological conditions in both observation years did not differ much from the long term mean and from each other (Table 2). Both years were slightly warmer than the long term mean of $9.9^{\circ} \mathrm{C}$ measured at a distance of approx. $5 \mathrm{~km}$ away (see Section 2.1). Furthermore, in the first year, annual precipitation exceeded the annual precipitation during the second year by approx. $10 \%$. Snow cover, which occurred during a few days in January, was also similar in both years. The annual course of radiation (PPFD) ranged from daily means of less than $10 \mu \mathrm{mol} \mathrm{m}^{-2} \mathrm{~s}^{-1}$ in winter to a maximum of $760 \mu \mathrm{mol} \mathrm{m}^{-2} \mathrm{~s}^{-1}$ at the end of June.

A more detailed look at the seasonal course of meteorological conditions, reveals some differences between the first year and the second year (Fig. 3a-e). On a seasonal basis, yr1 was

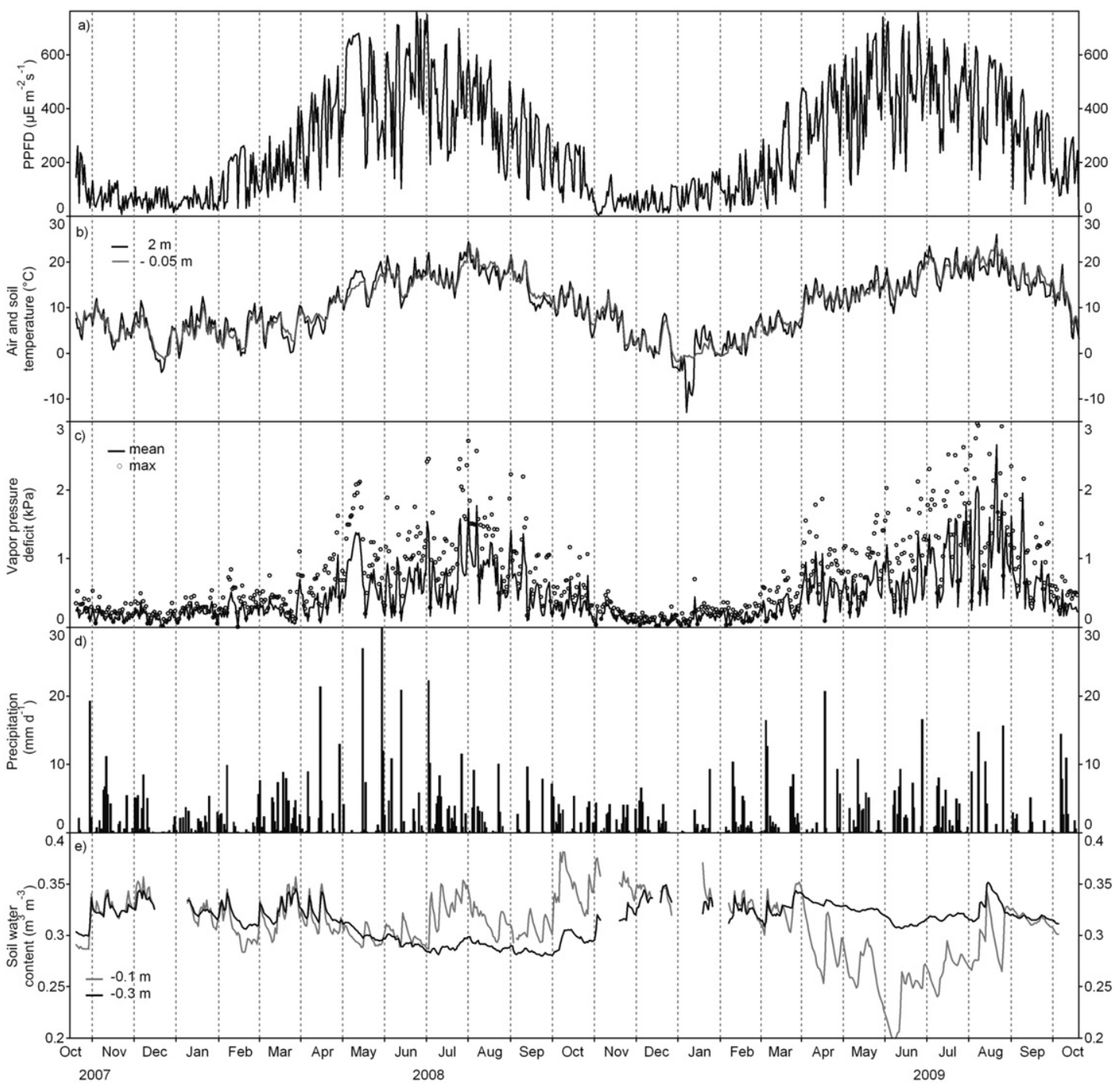

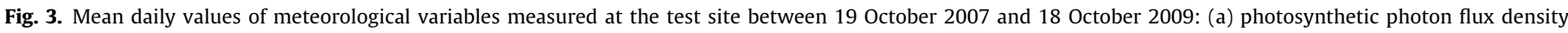
(PPFD $=0.45 \times 4.6 \times$ global radiation), (b) air- and soil temperature, (c) daytime vapor pressure deficit, (d) integrated precipitation, and (e) soil water content. 
Table 2

Annual statistics of air and soil temperature, photon flux density (PPFD), precipitation, daytime vapor pressure deficit (VPD) and soil water content (SWC) at the test site. yr1 refers to the period from 19 October 2007 to 18 October 2008 and yr2 to the period from 19 October 2008 to 18 October 2009.

\begin{tabular}{lcc}
\hline Variable & yr1 & yr2 \\
\hline Average air temperature $\left({ }^{\circ} \mathrm{C}\right)$ & 10.5 & 10.2 \\
Average soil temperature $\left({ }^{\circ} \mathrm{C}\right)$ & 10.4 & 10.5 \\
Average PPFD $\left(\mu \mathrm{mol} \mathrm{m} \mathrm{m}^{-2} \mathrm{~s}^{-1}\right)$ & 261 & 268 \\
Precipitation $(\mathrm{mm})$ & 768 & 700 \\
Average daytime VPD $(\mathrm{kPa})$ & 0.50 & 0.57 \\
Average SWC at $-0.1 \mathrm{~m}\left(\mathrm{~m}^{3} \mathrm{~m}^{-3}\right)$ & 31.7 & 30.5 \\
Average SWC at $-0.3 \mathrm{~m}\left(\mathrm{~m}^{3} \mathrm{~m}^{-3}\right)$ & 30.8 & 32.6 \\
\hline
\end{tabular}

Table 3

Results of the applied data rejection scheme on data coverage of 30-min measurements of net ecosystem exchange of $\mathrm{CO}_{2}$ (NEE). Percentages refer to a $100 \%$ data coverage of 35,088 possible observations during the two years of measurement (19 October 2007 to 18 October 2009). Instrument failure resulted mainly from problems with water on the sensor surface of the open path infrared gas analyzer.

\begin{tabular}{lcl}
\hline Criterion & Rejected (\%) & $\begin{array}{l}\text { (Resulting) } \\
\text { data coverage (\%) }\end{array}$ \\
\hline No measurements available & 4.9 & 95.1 \\
Instrument failure & 24.9 & 70.2 \\
Quality control & 25.8 & 44.4 \\
Footprint & 5 & 39.4 \\
\hline
\end{tabular}

slightly warmer in winter and slightly colder during spring and summer $\left(-0.6^{\circ} \mathrm{C}\right.$ between March and August), with the most pronounced difference between yr1 and yr2 in April (mean $8.5^{\circ} \mathrm{C}$ and $12.5^{\circ} \mathrm{C}$ respectively). On a monthly basis there were distinct differences in precipitation of up to $\pm 59 \%$, which are also represented in soil water content differences (Fig. 3e). From October to March, soil water content was more or less equal in both years, while from April to September clear differences were recorded. During this period, soil water content in $0.3 \mathrm{~m}$ was about $10 \%$ lower in yr2, while at the same time it was $9 \%$ higher in a depth of $0.1 \mathrm{~m}$. This behavior can be explained by the different timing and distribution of precipitation in both years. The mean vapor pressure deficits, with few exceptions, remained below $2 \mathrm{kPa}$. Maxima occurred during July and August in both years, while yr 2 shows slightly higher deficits. A period of exceptionally favorable growing conditions occurred in May of yr1 where 11 consecutive days had clear sky conditions, high temperatures and a reasonable soil water supply.

In contrast to seasonal meteorological conditions agricultural management was considerably different. Despite having been sown 33 days earlier in yr2, the first fertilization took place 18 days later as compared to yr1. The second and third fertilizer application occurred at about the same time in both years. The overall amount of applied fertilizer was $17 \%$ less in yr2. Time between sowing and harvesting was 261 and 284 days, respectively.

By applying the previously described rules to differentiate between MGS and oMGS, the duration of MGS in yr1 was 140 days (8 March-25 July) and 135 days (27 February-11 July) in yr2.

The observed crop properties (biomass and LAI) followed the typical annual cycle within the test site (Fig. 4). However, in spite of the differences in meteorological conditions and agricultural management, aboveground green biomass, indicated by the sum of leaf and stem dry matter, was similar in the beginning of March $\left(0.023\right.$ and $0.025 \mathrm{~kg} \mathrm{~m}^{-2}$ in yr1 and yr2, resp.). In both years, green LAI (GLAI) reached its maximum in the first half of May (5.6 and $5.9 \mathrm{~m}^{2} \mathrm{~m}^{-2}$ ). Leaf senescence, indicated by brown LAI (BLAI), started at the end of April. BLAI had its maximum of approximately $1.9 \mathrm{~m}^{2} \mathrm{~m}^{-2}$ in July of both years. However, the complete transformation from green to brown leaves occurred approx. 2 weeks earlier in yr2 as compared to yr1 (Fig. 4b). The aboveground green biomass maximum occurred in mid-June with values of $1.0 \mathrm{~kg} \mathrm{~m}^{-2}$ in yr1 and $1.3 \mathrm{~kg} \mathrm{~m}^{-2}$ in yr2. Due to the slower senescence in yr1 that is indicated by green leaves and ongoing photosynthesis in July, and due to earlier occurrence of flowering in yr1, there was more time for the assimilation of additional carbon. This resulted, together with other effects influencing the allocation of biomass to the plant organs (compare Dufranne et al., 2011), in a 12\% higher grain yield in yr1.

\subsection{Availability, quality, and uncertainty of eddy flux measurements}

The test for energy balance closure using Eq. (1) is known to reveal imbalances of about $20 \%$ even under ideal conditions for the EC method (Mahrt, 1998; Stannard et al., 1994; Twine et al., 2000; Foken, 2008; Wilson et al., 2002). The linear regression between available energy $(\mathrm{Q}-\mathrm{G})$ and the sum of energy fluxes $(\mathrm{H}+\mathrm{LE})$ yielded $0.8(\mathrm{Q}-\mathrm{G})+21.9$ with an $r^{2}$ of 0.9 .

The reason for the imbalance at our site is not clear. The analysis of the diurnal evolution of Res showed a time lag between available energy $(Q-G)$ and energy fluxes $(L E+H)$ of about $30 \mathrm{~min}$. Accounting for the storage terms of energy consumption due to photosynthesis and the crop enthalpy change according to Jacobs et al. (2008) improved the energy budget closure by $3 \%$, but did not

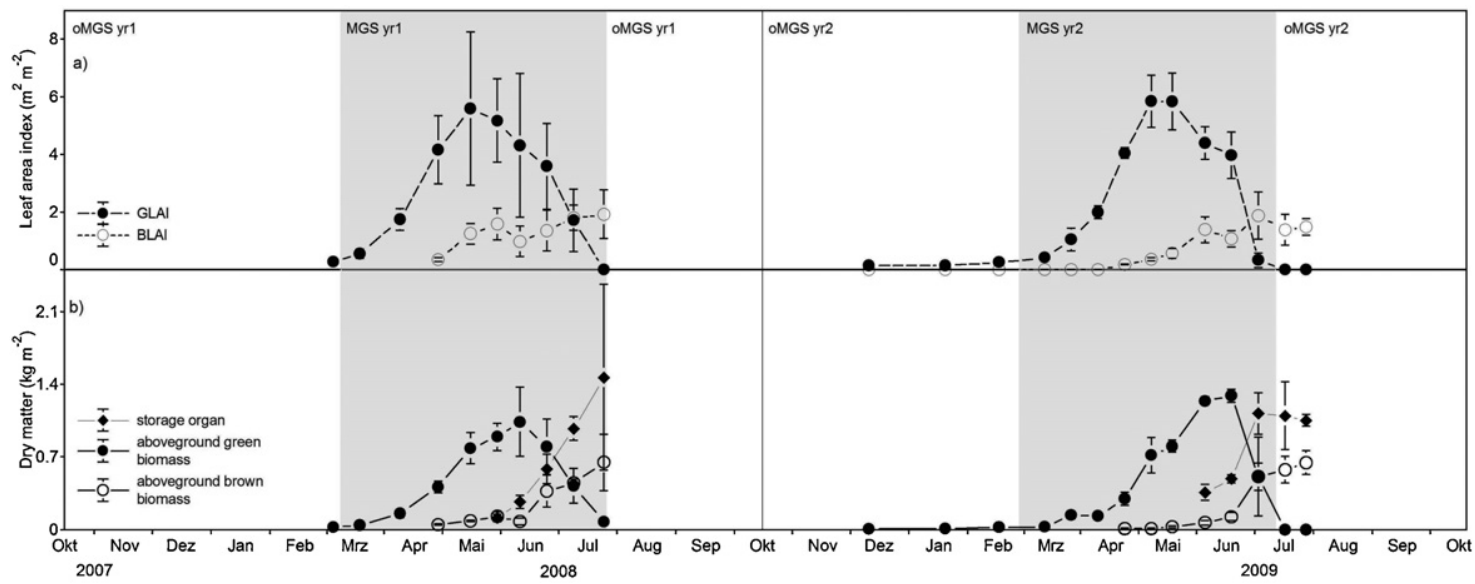

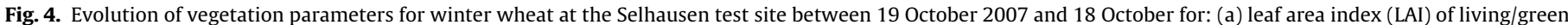

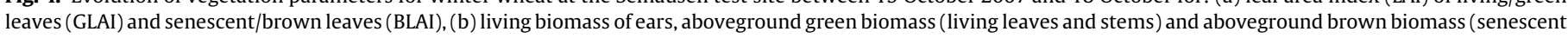
leaves and stems). The gray areas refer to the main growing seasons (MGS), as defined in Section 2.6 . 
decrease the time lag. Possibly, inaccurate measurements of soil heat flux $(G)$ with only one single sensor, sampling errors associated with differences in the source area of the used sensors (Wilson et al., 2002), and heterogeneity-induced and buoyancy-driven quasistationary circulations (Mauder et al., 2010) are reasons for the closure gap.

However, the result of our energy balance closure check is in good agreement with experiments and studies of carbon dioxide flux networks (Wilson et al., 2002; Foken et al., 2006). The mean diurnal residuals (range: -30 to $32 \mathrm{~W} \mathrm{~m}^{-2}$, mean: $7.8 \mathrm{~W} \mathrm{~m}^{-2}$ ) show lower amplitudes than Mauder and Foken (2006) reported for other agricultural sites.

Applying the data processing scheme (Fig. 2) to all 35088 possible $30 \mathrm{~min}$ records resulted in a data coverage of $39.4 \%$ for EC measured NEE (Table 3). An overview of the percentage of rejection by month is given in Fig. $5 \mathrm{~b}$. It indicates that besides instrument failure, the dominant source of rejection is quality control (mainly atmospheric stability). Applying a general footprint threshold of $80 \%$ CSC results in a data coverage of only $19 \%$. In this case the fraction of rejection due to instrument failure, quality control, and large footprint are similar (Fig. 5c, d). This is primarily caused by the large number of measurements during relatively stable stratification, which enlarge the footprint. As described in Section 2.3 thresholds of $50 \%$ at night and $70 \%$ for daytime observations were used for the further analysis.

The analysis of the temporal distribution of data availability and quality (Fig. 5a) revealed a distinct diurnal pattern during summer with highest availability and quality during daytime. This pattern is mainly the result of the turbulence conditions at the test site, which were well established during daytime, but more or less absent during nighttime and during transition periods. In winter, when days are shorter and stable periods were rarely interrupted by turbulent conditions, no obvious diurnal pattern was found and data availability and quality were generally lower. Thus during periods of large fluxes of carbon uptake (at daytime during the growing season) data coverage is good, whereas during periods of carbon release data coverage is generally worse. The latter also applies to nighttime fluxes during the growing season where fluxes are large. This is a general problem of the eddy covariance method, which is not applicable during nightly periods of stable stratification. To quantify the contribution of measured and filled data to the annual sum of NEE, the overall dataset was split into components with positive or negative signs. During the analyzed period, $69 \%$ of the data points with positive sign and $34 \%$ with negative sign are missing. In terms of carbon fluxes, $67 \%$ ( 749 of $1115 \mathrm{~g} \mathrm{C} \mathrm{m}^{-2}$ ) of the overall positive fluxes but only $16 \%\left(-260\right.$ of $\left.-1654 \mathrm{~g} \mathrm{C} \mathrm{m}^{-2}\right)$ of the negative fluxes are based on filled (i.e., modeled) data.

The uncertainty of the aggregated sums is not directly linked to the percentage of missing data. In addition, the distribution of gap lengths determines the overall uncertainty due to data gaps. In our dataset only $1 \%$ of the gaps shows a length of more than one day. The uncertainty analysis according to Richardson and Hollinger (2007) allows analyzing the effect of variable gap lengths upon the derived fluxes. The analysis revealed that the maximum uncertainty (in terms of standard deviation introduced into the annual NEE) for a gap of one day is between 0.004 and $0.26 \mathrm{~g} \mathrm{C} \mathrm{m}^{-2}$ (depending on the position of the gap in the time series). The uncertainty analysis resulted in an uncertainty of NEE due to gaps of $12 \mathrm{~g} \mathrm{C} \mathrm{m}^{-2}$ in yr1 and of $7 \mathrm{~g} \mathrm{Cm}^{-2}$ in yr2 (GPP: 8 and $15 \mathrm{~g} \mathrm{Cm}^{-2}$; $R_{\mathrm{eco}}: 15$ and $19 \mathrm{~g} \mathrm{C} \mathrm{m}^{-2}$ ).

The overall uncertainty including the uncertainty due to random instrument errors as calculated according to Richardson and Hollinger (2007) is shown in Table 4. Additional uncertainty arises from the advection of $\mathrm{CO}_{2}$ from neighboring fields as described in Section 2.3. This problem exists especially if (1) there is a different vegetation type on neighboring fields and (2) if the footprint is
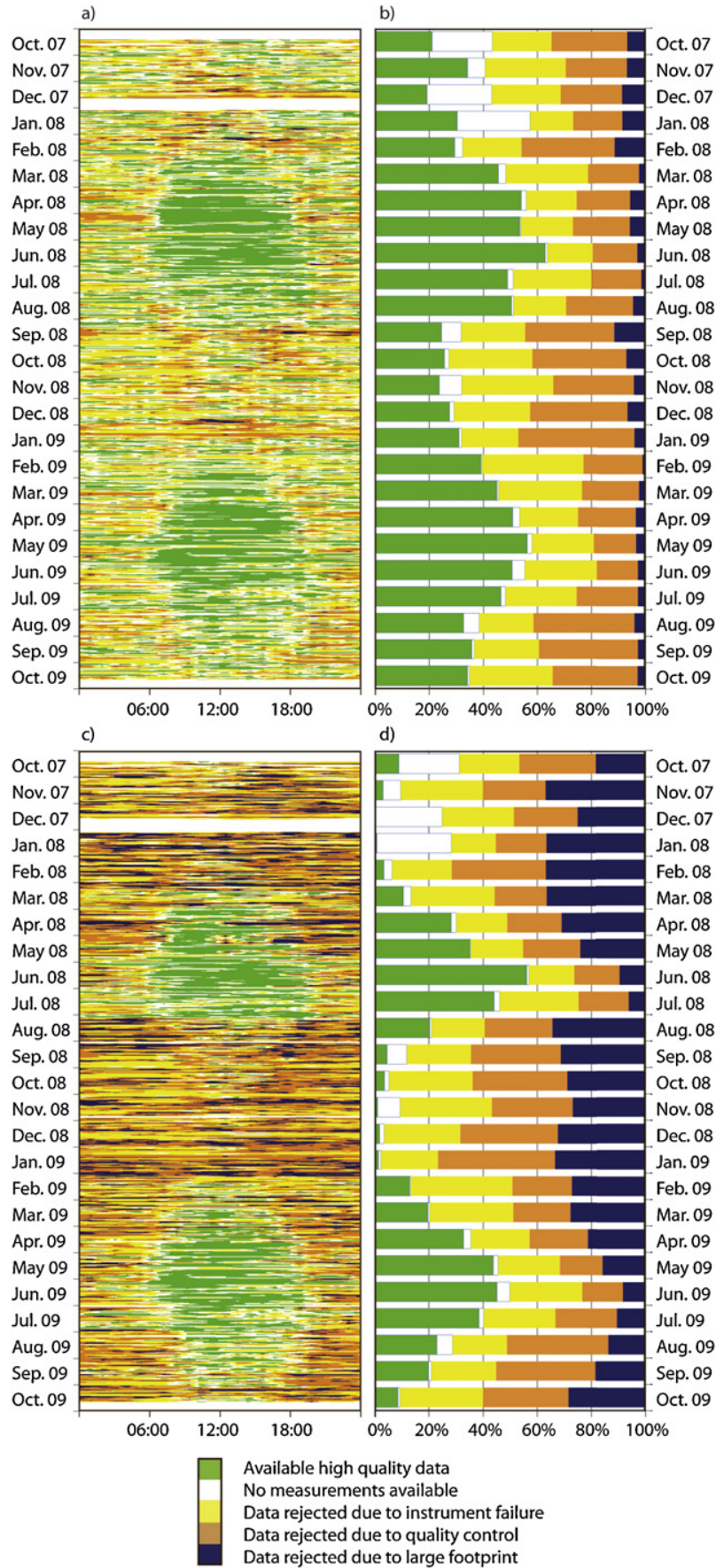

Fig. 5. Diurnal and seasonal (a, c) and monthly (b, d) distribution of data availability and rejection criteria for half-hourly NEE observations using individual cumulative source contribution (CSC) thresholds. (a), (c) 50\% CSC and 70\% CSC for night- and daytime observations, respectively. (c), (d) $80 \%$ CSC for all observations. All graphs represent the complete measurement period (19 October 2007 to 18 October 2009).

significantly larger than the test field. The latter applies particularly at stable stratification and after harvesting of the test-site when the distance between the instruments and the displacement height and thus the footprint increases. For this reason during periods of fully developed, green vegetation, the error due to pollution of the measured signal by air from outside the test-site can be assumed to be small. Especially during yr1 when winter wheat was grown on the adjacent fields only small effects can be expected during the MGS. In yr2, a maize field (A7 in Fig. 1) and several sugar beet fields (A4-A6) were located westward of the test site. Thus even the high 
Table 4

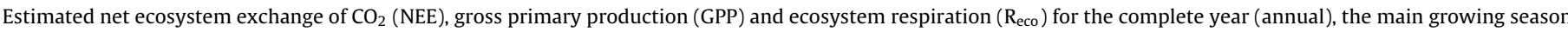

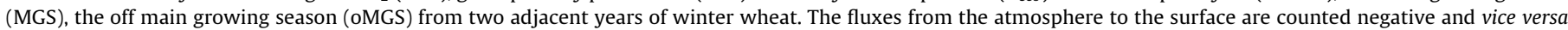
Values in parentheses denote uncertainty calculated according to Richardson and Hollinger (2007).

\begin{tabular}{|c|c|c|c|c|c|c|}
\hline \multirow[t]{2}{*}{ Carbon flux $\left(\mathrm{gC} \mathrm{m}^{-2}\right)$} & \multicolumn{3}{|l|}{ yr1 } & \multicolumn{3}{|l|}{ yr2 } \\
\hline & Annual & oMGS & MGS & Annual & oMGS & MGS \\
\hline NEE & $-270( \pm 19)$ & $358( \pm 12)$ & $-627( \pm 15)$ & $-270( \pm 18)$ & $268( \pm 12)$ & $-537( \pm 12)$ \\
\hline GPP & $-1351( \pm 18)$ & $-47( \pm 4)$ & $-1304( \pm 18)$ & $-1131( \pm 30)$ & $-64( \pm 10)$ & $-1067( \pm 27)$ \\
\hline $\mathrm{R}_{\text {eco }}$ & $1081( \pm 31)$ & $404( \pm 15)$ & $676( \pm 29)$ & $861( \pm 43)$ & $332( \pm 19)$ & $529( \pm 35)$ \\
\hline
\end{tabular}

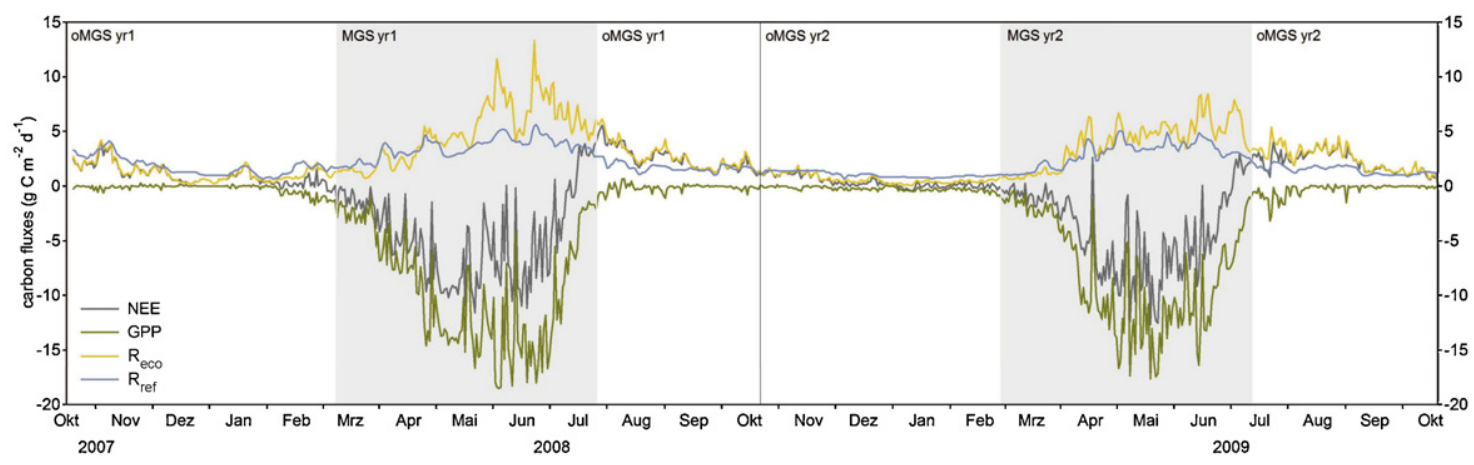

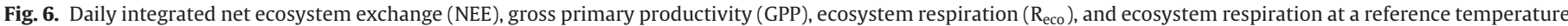
of $10^{\circ} \mathrm{C}\left(\mathrm{R}_{\mathrm{ref}}\right)$ between 19 October 2007 and 18 October 2009 at the Selhausen test site. The gray areas refer to the main growing seasons (MGS), as defined in Section 2.6 .

daytime CSC which is about $90 \%$ during that period did not prevent from contamination of the measured carbon flux.

After harvesting of the test-site, when GPP can be assumed to be zero, the advection effect can be estimated from the cumulative GPP for the periods between harvesting and sowing as 12 and $11 \mathrm{~g} \mathrm{C} \mathrm{m}^{-2}$ for yr 1 and yr2, respectively. This is less than $1 \%$ of the annual GPP and thus does not have a large influence on annual balances.

\subsection{Plausibility and distinctive features of filled time series}

The time series of daily integrated fluxes (Fig. 6) show a typical annual course with low values in oMGS and large fluxes in MGS. These characteristics, which are mainly caused by the seasonal development of biomass and its activity, are overlaid with fluctuations due to the natural variability of meteorological conditions. During both growing seasons, large day-to-day variations of up to $10 \mathrm{~g} \mathrm{C} \mathrm{m}^{-2} \mathrm{~d}^{-1}$ in GPP were observed. A correlation analysis between the non gapfilled half-hourly GPP and integrated daily PPFD during periods of GLAI $>3 \mathrm{~m}^{2} \mathrm{~m}^{-2}$ showed that $62 \%$ of this variation can be explained by fluctuating radiation supply. A good example of the influence of day-to-day variations of PPFD on GPP is the 11 day clear sky period of continuous high radiation during the first half of May in yr1 (Figs. 3 and 6) where GPP variations were below $1 \mathrm{gC} \mathrm{m}^{-2} \mathrm{~d}^{-1}$.

GPP showed maximum uptake rates of up to $19 \mathrm{~g} \mathrm{C} \mathrm{m}^{-2} \mathrm{~d}^{-1}$ in June 2008 and $18 \mathrm{~g} \mathrm{C} \mathrm{m}^{-2} \mathrm{~d}^{-1}$ in May 2009. In April and May, GPP was higher in yr2, while in June and July GPP was higher in yr1.

$\mathrm{R}_{\mathrm{eco}}$, which only indirectly depends on effects of radiation, shows a much smoother annual course with only a few peaks. The peaks in April and May of both years are mainly due to periods of higher temperatures. In June of yr1 two remarkable peaks with maximum values of 12 and $13 \mathrm{~g} \mathrm{C} \mathrm{m}^{-2} \mathrm{~d}^{-1}$ occurred during periods of daily mean temperatures around $20^{\circ} \mathrm{C}$. They are separated by a decline to $4 \mathrm{~g} \mathrm{C} \mathrm{m}^{-2} \mathrm{~d}^{-1}$ accompanying a $10^{\circ} \mathrm{C}$ temperature drop. The more constant course of $R_{\text {ref }}$ (reference respiration at a reference temperature of $10^{\circ} \mathrm{C}$ ) during this period supports the assumption that both peaks in $\mathrm{R}_{\text {eco }}$ were controlled primarily by temperature. In yr2 the $R_{\text {eco }}$ maxima were lower, peaking at about $8 \mathrm{~g} \mathrm{Cm}^{-2} \mathrm{~d}^{-1}$ with a double peak in the middle of June and a single one at the very beginning of July. Only the latter peak is accompanied by a maximum in temperature. The double peak coincides with a peak in $\mathrm{R}_{\mathrm{ref}}$ and therefore may be linked to the maximum of living biomass or the recovery of soil moisture from a relatively dry period since mid-May.

In addition to temporal fluctuations and pronounced peaks, high $R_{\text {eco }}$ with values of up to $3-4 \mathrm{~g} \mathrm{C} \mathrm{m}^{-2} \mathrm{~d}^{-1}$ in the beginning of $\mathrm{yr} 1$ and after harvesting of winter wheat in both years can be observed. These fluxes are caused by decomposition of roots and residues of the harvested crops. Although air temperature, as the main driving variable for respiration, was on average more than $10^{\circ} \mathrm{C}$ lower during the four week period after the sugar beet harvesting, values of $R_{\text {eco }}$ are of the same magnitude as after the harvesting of winter wheat in 2008 and 2009. Both, $R_{\text {eco }}$ and $R_{\text {ref }}$ increase after the sugar beet harvest. This shows that high respiration rates in this case are controlled mainly by higher water and substrate availability instead of temperature. This result is consistent with the more than 5 times higher amount of carbon left on the field after the sugar beet harvest as compared to the winter wheat (see Table 1) and with the findings of Aubinet et al. (2009) and Moureaux et al. (2006) who also found additional emissions associated with residue decomposition after sugar beet harvesting.

During the oMGS, where there were no or only small plants on the field, a continuously small GPP was detected. From sowing to the beginning of the MGS, this can be explained by low carbon uptake of small winter wheat plants. However, these measurements should be interpreted cautiously as the overall small fluxes from the test field may be contaminated by fluxes from neighboring fields.

Concerning the short term effects of management activities on carbon fluxes only minor effects were found. The most remarkable effects were (a) an increase of up to $5 \mathrm{~g} \mathrm{C} \mathrm{m}^{-2} \mathrm{~d}^{-1}$ in $\mathrm{R}_{\text {eco }}$ for up to 7 days, which was found after fertilization and (b) an increase of $R_{\text {eco }}$ of approx. $1 \mathrm{~g} \mathrm{C} \mathrm{m}^{-2} \mathrm{~d}^{-1}$ for a period of 5-6 days after ploughing. Although these observed short-term management impacts on $R_{\text {eco }}$ are in agreement with findings of other studies (e.g., Anthoni et al., 2004; Aubinet et al., 2009; Béziat et al., 2009) a clear cause-effect relationship can hardly be determined due to the small differences and a missing independent control field. 


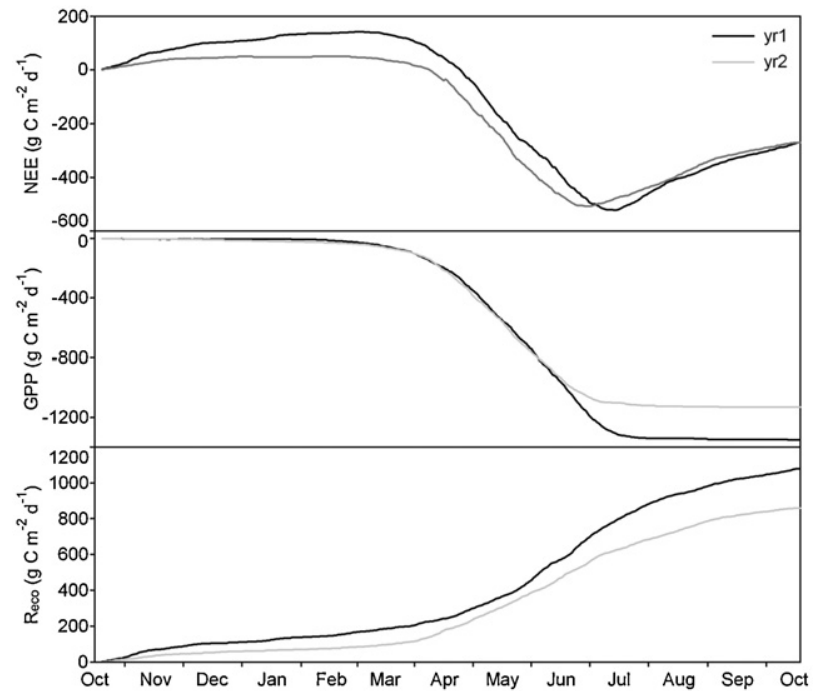

Fig. 7. Comparison of cumulative net ecosystem exchange (NEE), cumulative gross primary productivity (GPP), and cumulative ecosystem respiration $\left(\mathrm{R}_{\mathrm{eco}}\right)$ for the two observed years. yr1 (19 October 2007 to 18 October 2008); yr2 (19 October 2008 to 18 October 2009).

\subsection{Carbon budgets and inter-annual variability}

Although meteorological conditions, management activities, and thus crop development differed considerably, both years resulted in a cumulative NEE of $-270 \mathrm{~g} \mathrm{C} \mathrm{m}^{-2}$ (Table 4). In both years about $60 \%$ of $\mathrm{R}_{\text {eco }}$ occurred in the MGS. For GPP this fraction is above $94 \%$. Despite the similarities, fluxes show large inter-annual differences. GPP and $\mathrm{R}_{\text {eco }}$ are lower by $220 \mathrm{~g} \mathrm{C} \mathrm{m}^{-2} \mathrm{~d}^{-1}$ in yr2 as compared to yr1 (GPP $-16 \%, R_{\text {eco }}-20 \%$ ).

The differences between yr1 and yr2 can be most easily identified using the cumulative values (Fig. 7). From sowing until the beginning of March, GPP was always near zero (max $<-1 \mathrm{~g} \mathrm{C} \mathrm{m}^{-2} \mathrm{~d}^{-1}$, Fig. 6). Therefore, a larger $\mathrm{R}_{\mathrm{eco}}$ in yr1 resulted in more positive values of cumulative NEE during this period.

From the onset of MGS, 8 March in yr1 and 27 February in yr2, GPP increased to similar maxima of $-16 \mathrm{~g} \mathrm{C} \mathrm{m}^{-2} \mathrm{~d}^{-1}$ and $-17 \mathrm{~g} \mathrm{C} \mathrm{m}^{-2} \mathrm{~d}^{-1}$ in June of yr 1 and May of yr2, respectively. Despite these differences and the one month earlier sowing date in yr2, as well as the different meteorological conditions, cumulative GPP is almost equal until the beginning of June.

Until then differences of cumulative NEE are thus caused by differences in $R_{\text {eco. }}$ A lower $R_{\text {eco }}$ in yr2 caused the earlier transition from a carbon source to a carbon sink in yr2 (24 February) as compared to yr1 ( 3 March). Because of two early peaks in April in yr2, where $\mathrm{R}_{\text {eco }}$ exceeded the value determined for $\mathrm{yr} 1$, the offset between the two years of cumulative $R_{\text {eco }}$ and therefore also that of cumulative NEE becomes smaller. From mid-May to midJune, $R_{\text {eco }}$ of $y r 1$ exceeds that of $y r 2$ due to higher temperatures. A second reason for the increasing difference in cumulative $R_{\text {eco }}$ between the two years is the higher aboveground green and still respiring biomass (Fig. 4) between mid-June and the beginning of August. After harvesting until September of yr2, Reco generally remains above $3 \mathrm{~g} \mathrm{C} \mathrm{m}^{-2} \mathrm{~d}^{-1}$. In yr $1, R_{\text {eco }}$ is slightly more variable with a more pronounced decline below $2 \mathrm{~g} \mathrm{C} \mathrm{m}^{-2} \mathrm{~d}^{-1}$ after harvesting. From mid-September on, $\mathrm{R}_{\mathrm{eco}}$ declines in both years to values of about $1 \mathrm{gC} \mathrm{m}^{-2} \mathrm{~d}^{-1}$.

From mid-June onwards, the difference in cumulative GPP between the two years becomes more pronounced. The decrease of GPP in yr2 started in mid-June, corresponding to the earlier decrease of living aboveground biomass and GLAI (Fig. 4). In yr1, GPP remained at a high level until the end of June. Therefore the inflection point of cumulative NEE towards more positive values occurred earlier in yr2 than in yr1.

Only the higher $\mathrm{R}_{\mathrm{eco}}$ from June till the beginning of August in yr1 keeps the offset of cumulative NEE small. At the same time, it enhances the offset of cumulative $R_{\text {eco }}$ to an extent, which is sufficient to balance the higher GPP in yr1 resulting in almost the same annual NEE for both years.

To compare our results with those of the limited number of eddy covariance studies on winter wheat fields, we recalculated the budgets of our study to meet timing and duration of the other studies (Table 5). Therefore, we calculated two annual budgets (January to December and October to September) and one seasonal budget (sowing to harvesting). Comparing the annual budgets with sites in Gebesee (Anthoni et al., 2004), Lamasquère, and Auradé (Béziat et al., 2009), differences were generally in the same order of magnitude. Especially the relatively small differences in GPP and Reco published for the two French sites are noteworthy in comparison to our site since climatic conditions differ substantially and moreover, the monitored crops were a combination of winter wheat, rapeseed and triticale.

The comparison of the seasonal NEE budgets shows distinct differences (Table 5). In comparison to our test site, the largest differences in NEE were found in Jun et al. (2006) for the Yucheng site, with an average $76 \%$ smaller C sink, and in Aubinet (2008) for the Lonzée site, with a $44 \%$ larger sink. The low NEE of the Yucheng site is probably a result of the semi-humid and warm temperate climate with a short winter wheat season (negative NEE only from mid-March to end-May) and the lower daily carbon uptake rates due to shorter days. The large difference compared to the budgets in Lonzée are surprising, since the distance from our test-site is only about $130 \mathrm{~km}$ and climatic and soil conditions are similar. Moreover, GLAI and biomass, as reported in Moureaux et al. (2008) for the 2004/2005 winter wheat season in Lonzée, were smaller than at our site, while grain yield was similar. Despite, the unclear reason for the seasonal differences as compared to the Lonzée test site, our annual NEE budgets support the typical behavior of winter wheat in temperate climates.

To account for the total carbon balance of the field, i.e., to calculate NBP (net biome production), it is necessary to account for the carbon loss due to the removal of harvest (grain and straw) and the carbon input due to fertilization and sowing. Since no organic fertilizer was used during the observation period, the calculation of the NBP is simplified to the difference of NEE and carbon removal due to harvesting. According to yield data provided by the farm manager at our test site, a carbon importation of $8 \mathrm{~g} \mathrm{C} \mathrm{m}^{-2}$ due to sowing was estimated for both years. Due to harvesting 524 and $479 \mathrm{~g} \mathrm{C} \mathrm{m}^{-2}$ were removed in yr1 and yr2, respectively. The resulting NBP of 246 and $201 \mathrm{~g} \mathrm{C} \mathrm{m}^{-2}$ suggests that the field lost a substantial amount of carbon during the observation period. This surprisingly large carbon loss which would lead to a recognizable decline of soil organic carbon within several years, can be mainly associated to the substantial carbon input through the preceding sugar beet cultivation.

Based on the assumption that beet heads and leaves as well as $10 \%$ of the belowground biomass were left on the field as residues, a carbon input of roughly $750 \mathrm{~g} \mathrm{C} \mathrm{m}^{-2}$ can be derived from measured sugar beet biomass.

The overall fluxes with regard to the atmospheric carbon budget must also include the carbon consumption required for field operations (e.g., fuel), fertilizer, and agro-chemical production (e.g., West and Marland, 2002; Lal, 2004; Ceschia et al., 2010) as well as the energy required to dry the grains. Adopting estimates of carbon consumption due to field operations under US conditions from Lal (2004), assuming emission factors for applied fertilizer and agro-chemical amounts after Ceschia et al. (2010) and combining these with the typical regional energy consumption due to 
Table 5

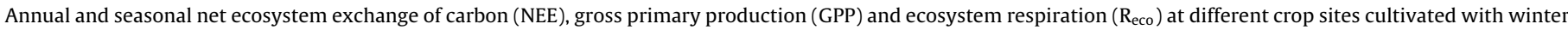

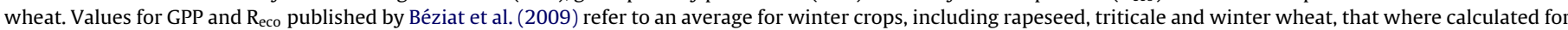

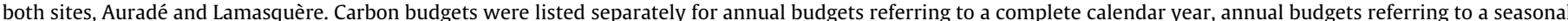

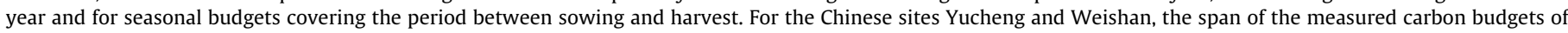
two, respectively four growing seasons is shown. Values in parentheses denote uncertainty, as provided by the related reference.

\begin{tabular}{|c|c|c|c|c|c|}
\hline Site & Year/season & NEE & GPP & $R_{\text {eco }}$ & Reference \\
\hline \multicolumn{6}{|l|}{ Calendar year } \\
\hline Gebesee (DE) & January-December 2001 & -185 to -245 & 1 & 1 & Anthoni et al. (2004) \\
\hline Selhausen (DE) & January-December 2008 & -252 & -1360 & 1108 & This study \\
\hline \multicolumn{6}{|l|}{ Seasonal year } \\
\hline Auradé (FR) & October 2005-September 2006 & $-324( \pm 20)$ & -1310 & 982 & Béziat et al. (2009) \\
\hline Lamasquère (FR) & October 2006-September 2007 & $-369( \pm 33)$ & -1310 & 982 & Béziat et al. (2009) \\
\hline Selhausen (DE) & October 2007-October 2008 & $-270( \pm 22)$ & $-1351( \pm 20)$ & $1081( \pm 16)$ & This study \\
\hline Selhausen (DE) & October 2008-October 2009 & $-270( \pm 22)$ & $-1131( \pm 22)$ & $861( \pm 17)$ & This study \\
\hline \multicolumn{6}{|l|}{ Growing season } \\
\hline Ponca City (US) & January 1996-August 1997 & -273 & -778 & 505 & Gilmanov et al. (2003) \\
\hline Yucheng $(\mathrm{CN})$ & October-June (2002-2004) & -78 to -152 & 1 & 1 & Jun et al. (2006) \\
\hline Weishan (CN) & October-August (2005-2009) & -303 to -395 & -782 to -1114 & 479 to -720 & Lei and Yang (2010) \\
\hline Lonzée (BE) & November 2004-August 2005 & $-630( \pm 30)$ & $-1580( \pm 130)$ & $950( \pm 130)$ & Aubinet et al. (2009) \\
\hline Lonzée (BE) & November 2006-August 2007 & $-730( \pm 40)$ & $-1680( \pm 120)$ & $950( \pm 120)$ & Aubinet et al. (2009) \\
\hline Selhausen (DE) & November 2007-August 2008 & -445 & -1338 & 836 & This study \\
\hline Selhausen (DE) & October 2008-July 2009 & -502 & -1120 & 674 & This study \\
\hline
\end{tabular}

the drying of winter wheat after harvest (KTBL, 2001), resulted in an additional carbon release of roughly $35 \mathrm{~g} \mathrm{C} \mathrm{m}^{-2} \mathrm{a}^{-1}$ which has to be added to the overall carbon balance of the test site. Taking into account that the drying of winter wheat consumes approx. $6 \mathrm{~g} \mathrm{C} \mathrm{m}^{-2} \mathrm{a}^{-1}$, this is similar to data from other winter wheat sites throughout Europe (approx. $29.6 \mathrm{~g} \mathrm{C} \mathrm{m}^{-2} \mathrm{a}^{-1} ; n=14$; Ceschia et al., 2010).

\section{Conclusion}

Seasonal and inter-annual variations of the NEE and its com-

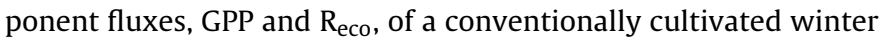
wheat field in Western Germany were analyzed, using two years of $\mathrm{CO}_{2}$ flux data as well as meteorological, soil, and biometric measurements. Data processing techniques and methods of flux partitioning and gap filling were adapted to the conditions of a crop field of limited size, which is typical for this intensively used crop area in Germany.

The seasonal carbon fluxes are strongly determined by the development of the winter wheat canopy, which was similar in both years, even though sowing dates differed by about one month and senescence appeared faster in the second year. In both years, carbon uptake became dominant in February and turned the wheat field into a carbon sink by March. After achievement of the mature stage, the field rapidly turned into a carbon source, due to heterotrophic respiration. The main difference in the carbon budgets between both years was the result of the longer biological activity of the winter wheat canopy in first year.

The results show that almost the same values of NEE and its uncertainty can occur for years with different management dates and differences in meteorological conditions. The longer biological activity in the first year was compensated by the more intensive heterotrophic respiration in the beginning of that year. Taking into account the amount of carbon removed from the field during harvest, the winter wheat field was found to be a carbon source to the atmosphere in both years. This considerable loss of soil carbon was probably compensated by the carbon input to the soil due to crop residues left on the field after harvest.

In general, the results underline the importance of multi-annual studies of carbon fluxes from arable fields, since carry over effects from preceding crops cannot be detected from single year measurements.

\section{Acknowledgements}

We gratefully acknowledge financial support by the project GLOWA-Danube, funded by the German Federal Ministry of Education and Research (BMBF-No. 56404005) and the SFB/TR 32 "Pattern in Soil-Vegetation-Atmosphere Systems: Monitoring, Modelling, and Data Assimilation" funded by the Deutsche Forschungsgemeinschaft (DFG). We also would like to thank A. Knaps from the Forschungszentrum Jülich for the provision of meteorological data. Special thanks go to our students for their assistance during field work, to farm manager F. Moes for granting access to his field, to Regine Spohner for cartography and figure layout, and to Karen Schneider for proofreading.

\section{References}

Ammann, C., Flechard, C.R., Leifeld, J., Neftel, A., Fuhrer, J., 2007. The carbon budget of newly established temperate grassland depends on management intensity. Agric. Ecosyst. Environ. 121, 136-146.

Anthoni, P.M., Freibauer, A., Kolle, O., Schulze, E.D., 2004. Winter wheat carbon exchange in Thuringia, Germany. Agric. Forest Meteorol. 121, 55-67.

Aubinet, M., 2008. Eddy covariance $\mathrm{CO}_{2}$ flux measurements in nocturnal conditions: an analysis of the problem. Ecol. Appl. 18, 1368-1378.

Aubinet, M., Grelle, A., Ibrom, A., Rannik, U., Moncrieff, J., Foken, T., Kowalski, A.S. Martin, P.H., Berbigier, P., Bernhofer, C., Clement, R., Elbers, J., Granier, A., Grunwald, T., Morgenstern, K., Pilegaard, K., Rebmann, C., Snijders, W., Valentini, R., Vesala, T., 2000. Estimates of the annual net carbon and water exchange of forests: the EUROFLUX methodology. Adv. Ecol. Res. 30, 114-175.

Aubinet, M., Moureaux, C., Bodson, B., Dufranne, D., Heinesch, B., Suleau, M., Vancutsem, F., Vilret, A., 2009. Carbon sequestration by a crop over a 4-year sugar beet/winter wheat/seed potato/winter wheat rotation cycle. Agric. Forest Meteorol. 149, 407-418.

Baldocchi, D.D., 2003. Assessing the eddy covariance technique for evaluating carbon dioxide exchange rates of ecosystems: past, present and future. Glob. Change Biol. 9, 479-492.

Bavin, T.K., Griffis, T.J., Baker, J.M., Venterea, R.T., 2009. Impact of reduced tillage and cover cropping on the greenhouse gas budget of a maize/soybean rotation ecosystem. Agric. Ecosyst. Environ. 134, 234-242.

Béziat, P., Ceschia, E., Dedieu, G., 2009. Carbon balance of a three crop succession over two cropland sites in South West France. Agric. Forest Meteorol. 149, 1628-1645.

Campbell, G.S., Norman, J.M., 1998. Introduction to Environmental Biophysics. Springer-Verlag, New York.

Campbell Scientific, 2003. HFT3 Soil Heat Flux Plate. Campbell Scientific, Inc., Logan, USA.

Ceschia, E., Béziat, P., Dejoux, J.F., Aubinet, M., Bernhofer, C., Bodson, B., Buchmann, N., Carrara, A., Cellier, P., Di Tommasi, P., Elbers, J.A., Eugster, W., Gruenwald, T., Jacobs, C.M.J., Jans, W.W.P., Jones, M., Kutsch, W., Lanigan, G., Magliulo, E., Marloie, O., Moors, E.J., Moureaux, C., Olioso, A., Osborne, B., Sanz, M.J., Saunders, M., Smith, P., Soegaard, H., Wattenbach, M., 2010. Management effects on net ecosystem carbon and GHG budgets at european crop sites. Agric. Ecosyst. Environ. 139, 363-383.

Ciais, P., Wattenbach, M., Vuichard, N., Smith, P., Piao, S.L., Don, A., Luyssaert, S. Janssens, I.A., Bondeau, A., Dechow, R., Leip, A., Smith, P.C., Beer, C., van der Werf, 
G.R., Gervois, S., Van Oost, K., Tomelleri, E., Freibauer, A., Schulze, E.D., 2010. The European carbon balance. Part 2: Croplands. Glob. Change Biol. 16, 1409-1428.

Dufranne, D., Moureaux, C., Vancutsem, F., Bodson, B., Aubinet, M., 2011. Comparison of carbon fluxes, growth and productivity of a winter wheat crop in three contrasting growing seasons. Agric. Ecosyst. Environ. 141, 133-142.

Falge, E., Baldocchi, D., Olson, R., Anthoni, P., Aubinet, M., Bernhofer, C., Burba, G., Ceulemans, G., Clement, R., Dolman, H., Granier, A., Gross, P., Grunwald, T., Hollinger, D., Jensen, N.O., Katul, G., Keronen, P., Kowalski, A., Lai, C.T., Law, B.E., Meyers, T., Moncrieff, J., Moors, E., Munger, J.W., Pilegaard, K., Rannik, U., Rebmann, C., Suyker, A., Tenhunen, J., Tu, K., Verma, S., Vesala, T., Wilson, K., Wofsy, S., 2001a. Gap filling strategies for long term energy flux data sets. Agric. Forest Meteorol. 107, 71-77.

Falge, E., Baldocchi, D., Olson, R., Anthoni, P., Aubinet, M., Bernhofer, C., Burba, G., Ceulemans, R., Clement, R., Dolman, H., Granier, A., Gross, P., Grunwald, T., Hollinger, D., Jensen, N.O., Katul, G., Keronen, P., Kowalski, A., Lai, C.T., Law, B.E., Meyers, T., Moncrieff, H., Moors, E., Munger, J.W., Pilegaard, K., Rannik, U., Rebmann, C., Suyker, A., Tenhunen, J., Tu, K., Verma, S., Vesala, T., Wilson, K., Wofsy, S., 2001b. Gap filling strategies for defensible annual sums of net ecosystem exchange. Agric. Forest Meteorol. 107, 43-69.

FAO, 2007. FAO Statistical Databases. Available on http://faostat.fao.org/.

Foken, T., 2003. Angewandte Meteorologie. Mikrometeorologische Methoden. Springer, Heidelberg.

Foken, T., 2008. The energy balance closure problem: an overview. Ecol. Appl. 18, 1351-1367.

Foken, T., Göckede, M., Mauder, M., Mahrt, L., Amiro, B., Munger, J., 2004. Postfield data quality control. In: Lee, X., Massman, W.J., Law, B. (Eds.), Handbook of Micrometeorology: A Guide for Surface Flux Measurement and Analysis. Kluwer Academic Press, Dordrecht, pp. 181-203.

Foken, T., Wichura, B., 1996. Tools for quality assessment of surface-based flux measurements. Agric. Forest Meteorol. 78, 83-105.

Foken, T., Wimmer, F., Mauder, M., Thomas, C., Liebethal, C., 2006. Some aspects of the energy balance closure problem. Atmos. Chem. Phys. 6, 4395-4402.

Freibauer, A., Rounsevell, M.D.A., Smith, P., Verhagen, J., 2004. Carbon sequestration in the agricultural soils of Europe. Geoderma 122, 1-23.

Gilmanov, T.G., Verma, S.B., Sims, P.L., Meyers, T.P., Bradford, J.A., Burba, G.G., Suyker, A.E., 2003. Gross primary production and light response parameters of four Southern Plains ecosystems estimated using long-term $\mathrm{CO}_{2}$-flux tower measurements. Global Biogeochem. Cy. 17, 40.1-40.16.

Goidts, E., van Wesemael, B., van Oost, K., 2009. Driving forces of soil organic carbon evolution at the landscape and regional scale using data from a stratified soil monitoring. Glob. Change Biol. 15, 2981-3000.

Greco, S., Baldocchi, D.D., 1996. Seasonal variations of $\mathrm{CO}_{2}$ and water vapour exchange rates over a temperate deciduous forest. Glob. Change Biol. 2, 183-197.

Grelle, A., Lindroth, A., 1996. Eddy-correlation system for long-term monitoring of fluxes of heat, water vapour and $\mathrm{CO}_{2}$. Glob. Change Biol. 2, 297-307.

Heusinkveld, B.G., Jacobs, A.F.G., Holtslag, A.A.M., 2008. Effect of open-path gas analyzer wetness on eddy covariance flux measurements: a proposed solution. Agric. Forest Meteorol. 148, 1563-1573.

Hojstrup, J., 1981. A simple-model for the adjustment of velocity spectra in unstable conditions downstream of an abrupt change in roughness and heat-flux. Bound.Lay. Meteorol. 21, 341-356.

Hollinger, D.Y., Kelliher, F.M., Byers, J.N., Hunt, J., McSeveny, T.M., Weir, P., 1994. Carbon-dioxide exchange between an undisturbed old-growth temperate forest and the atmosphere. Ecology 75, 134-150.

IUSS Working Group WRB, 2006. World Reference Base for Soil Resources 2006. FAO, Rome.

Jacobs, A.F.G., Heusinkveld, B.G., Holtslag, A.A.M., 2008. Towards closing the surface energy budget of a mid-latitude grassland. Bound.-Lay. Meteorol. 126, 125-136.

Janssens, I., Freibauer, A., Schlamadinger, B., Ceulemans, R., Ciais, P., Dolman, A., Heimann, M., Nabuurs, G., Smith, P., Valentini, R., Schulze, E., 2005. The carbon budget of terrestrial ecosystems at country-scale - a European case study. Biogeosciences 2, 15-26.

Jun, L., Qiang, Y., Xiaomin, S., Xiaojuan, T., Chuanyou, R., Jing, W., Enmin, L., Zhilin, Z., Guirui, Y., 2006. Carbon dioxide exchange and the mechanism of environmental control in a farmland ecosystem in North China Plain. Sci. China Ser. D 49, 226-240.

Kaimal, J.C., Izumi, Y., Wyngaard, J.C., Cote, R., 1972. Spectral characteristics of surface-layer turbulence. Q. J. Roy. Meteor. Soc. 98, 563-589.

Kormann, R., Meixner, F.X., 2001. An analytical footprint model for non-neutral stratification. Bound.-Lay. Meteorol. 99, 207-224.

KTBL (Ed.), 2009. Faustzahlen der Landwirtschaft. Kuratorium für Technik und Bauwesen in der Landwirtschaft e.V., Darmstadt. 14 edition.

Kutsch, W.L., Aubinet, M., Buchmann, N., Smith, P., Osborne, B., Eugster, W., Wattenbach, M., Schrumpf, M., Schulze, E.D., Tomelleri, E., Ceschia, E., Bernhofer, C., Béziat, P., Carrara, A., Di Tommasi, P., Gruenwald, T., Jones, M., Magliulo, V., Marloie, O., Moureaux, C., Olioso, A., Sanz, M.J., Saunders, M., Sogaard, H., Ziegler, W., 2010. The net biome production of full crop rotations in Europe. Agric. Ecosyst. Environ. 139, 336-345.

Lal, R., 2004. Carbon emission from farm operations. Environ. Int. 30, 981-990.

Lal, R., Kimble, J., 1997. Conservation tillage for carbon sequestration. Nutr. Cycl. Agroecosyst. 49, 243-253.

Lei, H.M., Yang, D.W., 2010. Seasonal and interannual variations in carbon dioxide exchange over a cropland in the North China Plain. Glob. Change Biol. 16, 2944-2957.

Leuning, R., Judd, M.J., 1996. The relative merits of open- and closed-path analysers for measurement of eddy fluxes. Glob. Change Biol. 2, 241-253.
Liu, H., Peters, G., Foken, T., 2001. New equations for sonic temperature variance and buoyancy heat flux with an omnidirectional sonic anemometer. Bound.-Lay. Meteorol. 100, 459-468.

Lloyd, J., Taylor, J.A., 1994. On the temperature-dependence of soil respiration. Funct. Ecol. 8, 315-323.

Mahrt, L., 1998. Flux sampling errors for aircraft and towers. J. Atmos. Ocean. Tech. $15,416-429$.

Mauder, M., Desjardins, R.L., Pattey, E., Worth, D., 2010. An attempt to close the daytime surface energy balance using spatially-averaged flux measurements. Bound.-Lay. Meteorol. 136, 175-191.

Mauder, M., Foken, T., 2004. Documentation and instruction manual of the eddy covariance software package TK2. Universität Bayreuth, Abteilung Mikrometeorologie, Bayreuth, Germany.

Mauder, M., Foken, T., 2006. Impact of post-field data processing on eddy covariance flux estimates and energy balance closure. Meteorol. Z 15, 597-609.

Meek, D., Hatfield, J.L., Howell, T., Idso, S., Reginato, R., 1984. A generalized relationship between photosynthetically active radiation and solar radiation. Agron. J 76, 939-945.

Meier, U., 2001. Growth stages of mono- and dicotyledonous plants, 2nd ed. BBCH Monograph. Biologische Bundesanstalt für Land- und Forstwirtschaft Braunschweig-Berlin.

Moore, C.J., 1986. Frequency-response corrections for eddy-correlation systems. Bound.-Lay. Meteorol. 37, 17-35.

Moureaux, C., Debacq, A., Bodson, B., Heinesch, B., Aubinet, M., 2006. Annual net ecosystem carbon exchange by a sugar beet crop. Agric. Forest Meteorol. 139, 25-39.

Moureaux, C., Debacq, A., Hoyaux, J., Suleau, M., Tourneur, D., Vancutsem, F., Bodson, B., Aubinet, M., 2008. Carbon balance assessment of a Belgian winter wheat crop (Triticum aestivum L.). Glob. Change Biol. 14, 1353-1366.

Neftel, A., Spirig, C., Ammann, C., 2008. Application and test of a simple tool for operational footprint evaluations. Environ. Pollut. 152, 644-652.

Rabinowitch, E., 1951. Photosynthesis and Related Processes. Interscience Publishers, New York

Reichstein, M., Falge, E., Baldocchi, D., Papale, D., Aubinet, M., Berbigier, P., Bernhofer, C., Buchmann, N., Gilmanov, T., Granier, A., Grunwald, T., Havrankova, K. Ilvesniemi, H., Janous, D., Knohl, A., Laurila, T., Lohila, A., Loustau, D., Matteucci, G., Meyers, T., Miglietta, F., Ourcival, J.M., Pumpanen, J., Rambal, S., Rotenberg, E., Sanz, M., Tenhunen, J., Seufert, G., Vaccari, F., Vesala, T., Yakir, D., Valentini, R., 2005. On the separation of net ecosystem exchange into assimilation and ecosystem respiration: review and improved algorithm. Glob. Change Biol. 11.

Reynolds, O., 1894. On the dynamical theory of incompressible viscous fluid and the determination of the criterion. Proc. Roy. Soc. A: Math. Phys. 56, 40-45.

Richardson, A.D., Hollinger, D.Y., 2005. Statistical modeling of ecosystem respiration using eddy covariance data: maximum likelihood parameter estimation, and Monte Carlo simulation of model and parameter uncertainty, applied to three simple models. Agric. Forest Meteorol. 131, 191-208.

Richardson, A.D., Hollinger, D.Y., 2007. A method to estimate the additional uncertainty in gap-filled nee resulting from long gaps in the $\mathrm{CO}_{2}$ flux record. Agric Forest Meteorol. 147, 199-208.

Saito, M., Miyata, A., Nagai, H., Yamada, T., 2005. Seasonal variation of carbon dioxide exchange in rice paddy field in Japan. Agric. Forest Meteorol. 135

Schotanus, P., Nieuwstadt, F.T.M., Debruin, H.A.R., 1983. Temperature-measurement with a sonic anemometer and its application to heat and moisture fluxes. Bound.Lay. Meteorol. 26, 81-93.

Schulze, E.D., Ciais, P., Luyssaert, S., Schrumpf, M., Janssens, I.A., Thiruchittampalam, B., Theloke, J., Saurat, M., Bringezu, S., Lelieveld, J., Lohila, A., Rebmann, C., Jung M., Bastviken, D., Abril, G., Grassi, G., Leip, A., Freibauer, A., Kutsch, W., Don, A. Nieschulze, J., Boerner, A., Gash, J.H., Dolman, A.J., 2010. The European carbon balance. Part 4: Integration of carbon and other trace-gas fluxes. Glob. Change Biol. 16, 2399-2399.

Serrano-Ortiz, P., Kowalski, A.S., Domingo, F., Ruiz, B., ados Arboledas, L., 2008. Consequences of uncertainties in $\mathrm{CO}_{2}$ density for estimating net ecosystem $\mathrm{CO}_{2}$ exchange by open-path eddy covariance. Bound.-Lay. Meteorol. 126, 209-218.

Smith, P., 2004. Carbon sequestration in croplands: the potential in Europe and the global context. Eur. J. Agron. 20, 229-236.

Smith, P., Martino, D. Cai, Z., Gwary, D., Janzen, H., Kumar, P., McCarl, B., Ogle, S., O'Mara, F., Rice, C., Scholes, B., Sirotenko, O., 2007. Contribution of Working Group III to the Fourth Assessment Report of the Intergovernmental Panel on Climate Change. In: Metz, B., Davidson, O., Bosch, P., Dave, R., Meyer, L. (Eds.) Climate Change 2007: Mitigation. Cambridge University Press, United Kingdom and New York, NY, USA. Chapter Agriculture.

Stannard, D.I., Blanford, J.H., Kustas, W.P., Nichols, W.D., Amer, S.A., Schmugge, T.J., Weltz, M.A., 1994. Interpretation of surface flux measurements in heterogeneous terrain during the monsoon 90 experiment. Water Resour. Res. 30, 1227-1239.

Suyker, A.E., Verma, S.B., Burba, G.G., Arkebauer, T.J., 2005. Gross primary production and ecosystem respiration of irrigated maize and irrigated soybean during a growing season. Agric. Forest Meteorol. 131, 180-190.

Twine, T.E., Kustas, W.P., Norman, J.M., Cook, D.R., Houser, P.R., Meyers, T.P., Prueger J.H., Starks, P.J., Wesely, M.L., 2000. Correcting eddy-covariance flux underestimates over a grassland. Agric. Forest Meteorol. 103, 279-300.

Verma, S., Dobermann, A., Cassman, K., Walters, D., Knops, J., Arkebauer, T., Suyker, A. Burba, G., Amos, B., Yang, H., Ginting, D., Hubbard, K., Gitelson, A., Walter-Shea, E., 2005. Annual carbon dioxide exchange in irrigated and rainfed maize-based agroecosystems. Agric. Forest Meteorol. 131, 77-96. 
Vickers, D., Mahrt, L., 1997. Quality control and flux sampling problems for tower and aircraft data. J. Atmos. Ocean. Technol. 14, 512-526.

Webb, E.K., Pearman, G.I., Leuning, R., 1980. Correction of flux measurements for density effects due to heat and water-vapor transfer. Q.J. Roy. Meteor. Soc. 106, 85-100.

West, T., Marland, G., 2002. Net carbon flux from agricultural ecosystems: methodology for full carbon cycle analyses. Environ. Pollut. 116, 439-444.
Wilczak, J.M., Oncley, S.P., Stage, S.A., 2001. Sonic anemometer tilt correction algorithms. Bound.-Lay. Meteorol. 99, 127-150.

Wilson, K., Goldstein, A., Falge, E., Aubinet, M., Baldocchi, D., Berbigier, P., Bernhofer C., Ceulemans, R., Dolman, H., Field, C., Grelle, A., Ibrom, A., Law, B.E., Kowalski, A., Meyers, T., Moncrieff, J., Monson, R., Oechel, W., Tenhunen, J., Valentini, R., Verma, S., 2002. Energy balance closure at FLUXNET sites. Agric. Forest Meteorol $113,223-243$. 